

\section{DISCLAIMER}

This report was prepared as an account of work sponsored by an agency of the United States Government. Neither the United States Government nor any agency Thereof, nor any of their employees, makes any warranty, express or implied, or assumes any legal liability or responsibility for the accuracy, completeness, or usefulness of any information, apparatus, product, or process disclosed, or represents that its use would not infringe privately owned rights. Reference herein to any specific commercial product, process, or service by trade name, trademark, manufacturer, or otherwise does not necessarily constitute or imply its endorsement, recommendation, or favoring by the United States Government or any agency thereof. The views and opinions of authors expressed herein do not necessarily state or reflect those of the United States Government or any agency thereof. 


\section{DISCLAIMER}

Portions of this document may be illegible in electronic image products. Images are produced from the best available original document. 


\title{
SUMMARY OF THE RADIOLOGICAL ASSESSMENT OF THE FUEL CYCLE FOR A THORIUM-URANIUM CARBIDE-FUELED FAST BREEDER REACTOR
}

\author{
V.J. Tennery E.S. Bomar W. D. Bond H. R. Meyer \\ L. E. Morse J. E. Till M. G. Yalcintas
}

Date Published: January 1980

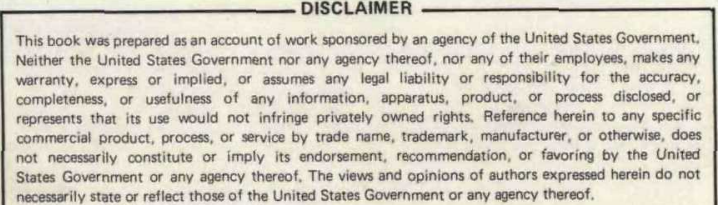

NOTICE This document contains information of a preliminary nature. It is subject to revision or correction and therefore does not represent a final report.

OAK RIDGE NATIONAL LABORATORY

Oak Ridge, Tennessee 37830 operated by

UNION CARBIDE CORPORATION for the DEPARTMENT OF ENERGY
This document is PUBLICLY RELEASABLE DaveHamrin, ORNL Authorizing Official Date $1-11-2012$ 
ORNL/TM-6953

Distribution Category

UC.79b,-c

Contract No. W-7405-eng-26

METALS AND CERAMICS DIVISION

CHEMICAL TECHNOLOGY DIVISION

HEALTH AND ENVIRONMENTAL SAFETY DIVISION

\title{
SUMMARY OF THE RADIOLOGICAL ASSESSMENT OF THE FUEL CYCLE FOR A THORIUM-URANIUM CARBIDE-FUELED FAST BREEDER REACTOR
}

\author{
V.J. Tennery E.S. Bomar W. D. Bond H. R. Meyer \\ L. E. Morse J. E. Till M. G. Yalcintas
}

Date Published: January 1980

NOTICE This document contains information of a prelıminary nature. It is subject to revision or correction and therefore does not represent a final report.

OAK RIDGE NATIONAL LABORATORY

Oak Ridge, Tennessee 37830 operated by

UNION CARBIDE CORPORATION

for the

DEPARTMENT OF ENERGY 


\section{CONTENTS}

ABSTRACT

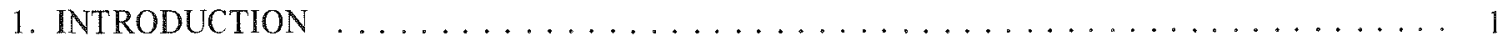

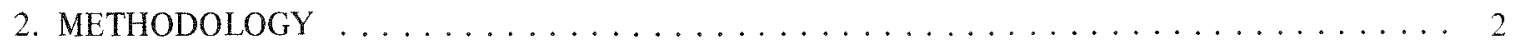

3. RADIOCHARACTERISTICS OF THORIUM AND DAUGHTERS $\ldots \ldots \ldots \ldots \ldots \ldots \ldots$

4. MINING, MILLING, AND REFINING OF THORIUM $\ldots \ldots \ldots \ldots \ldots \ldots \ldots \ldots$

4.1 Description of Model Mine and Mill $\ldots \ldots \ldots \ldots \ldots \ldots \ldots \ldots \ldots \ldots \ldots$

4.2 Source Terms from Mining, Milling, and Refining $\ldots \ldots \ldots \ldots \ldots \ldots \ldots \ldots$

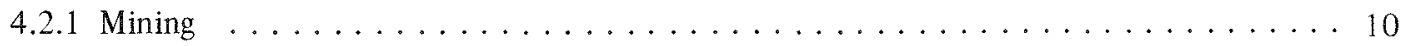

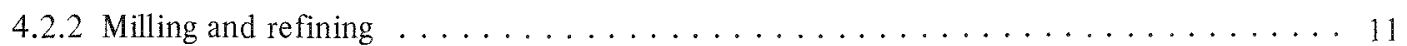

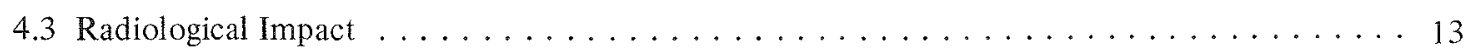

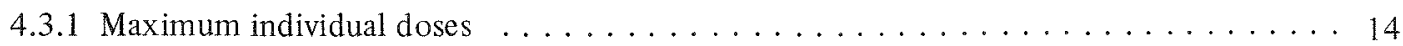

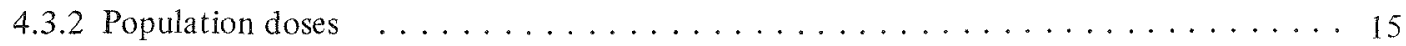

5. REPROCESSING AND REFABRICATION OF $\left({ }^{232} \mathrm{Th}^{233} \mathrm{U}\right)$ CARBIDE FUELS $\ldots \ldots \ldots \ldots$

5.1 Description of Reprocessing and Refabrication Plants $\ldots \ldots \ldots \ldots \ldots \ldots \ldots \ldots$

5.2 Source Terms from Reprocessing and Refabrication $\ldots \ldots \ldots \ldots \ldots \ldots \ldots \ldots \ldots$

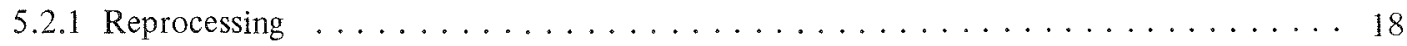

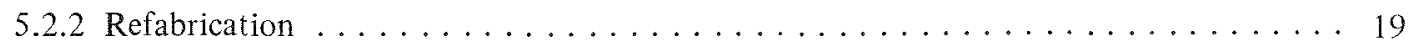

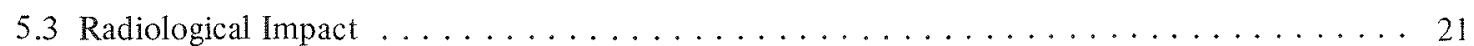

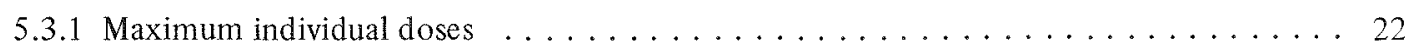

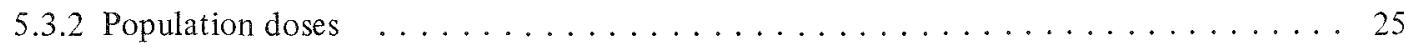

5.3.3 Radiological importance of ${ }^{232} \mathrm{U}$ in recycle of $\left({ }^{232} \mathrm{Th},{ }^{233} \mathrm{U}\right) \mathrm{C}$ fuel $\ldots \ldots \ldots \ldots 26$

5.3.4 Radiological importance of tritium in reprocessing of $\left({ }^{232} \mathrm{Th},{ }^{233} \mathrm{U}\right) \mathrm{C}$ fuel $\ldots \ldots \ldots 26$

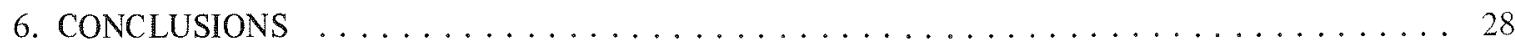

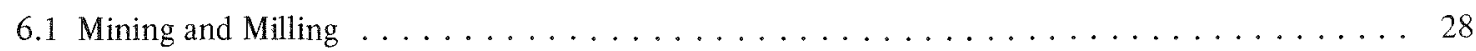

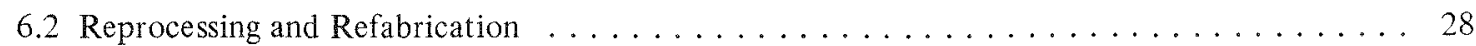

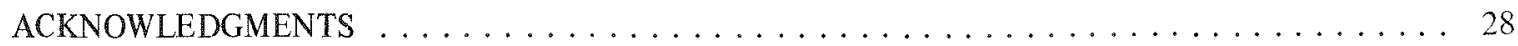

REFERENCES . . . . . . . . . . . . . . . . . . . . . . . . . . . . . . . . . . . 29 


\title{
SUMMARY OF THE RADIOLOGICAL ASSESSMENT OF THE FUEL CYCLE FOR A THORIUM-URANIUM CARBIDE-FUELED FAST BREEDER REACTOR*
}

\author{
V J Tennery ${ }^{\dagger}$ E S Bomar ${ }^{\dagger}$ W D Bond ${ }^{\dagger}$ H R Meyer $\$$ \\ L E Morse J E Till $\S, \|$ M G Yalcintas
}

\begin{abstract}
A large fraction of the potential fuel for nuclear power reactors employing fissionable materials exists as ores of thorium In addition, certan characteristics of a fuel system based on breeding of the fisstonable 1sotope ${ }^{233} \mathrm{U}$ trom thorium offer the possibility of a greater resistance to the diverston of tissionable material for the fabrication of nuclear weapons This report consolidates into a single source the principal content of two previous reports which assess the radiological environmental impact of mining and milling of thorium ore and of the reprocessing and refabrication of spent $\mathrm{BR}$ thorium uranium carbide fuel

I nvironmental assessment involves two major steps The first is the selection of source terms that describe the rate and physical and chemical forms of radiodctivity released from the required processes, and the second is the calculation of the resulting dose to a maximally exposed individual and the general population near the site Reledses from the processing of thorium ores or thorium-based

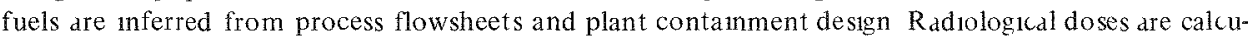
lated through use of environmental and dosimetric models

Lung is the critical organ for a maximally exposed individual located $16 \mathrm{~km}$ trom a mine and mill site, receiving a dose of 353 millirems Radon-220 decay products are the principal contributors, ${ }^{228} \mathrm{Rd}$ is second in importance Thyroid recetves the highest dose $\left(68 \mathrm{mill}\right.$ irems from $\left.{ }^{129} \mathrm{I}\right)$ for an individual locdted $1 \mathrm{~km}$ from the reprocessing plant, but tritium contributes more than $60 \%$ of the dose to total body, lungs, and other organs Cesium-137, ${ }^{14} \mathrm{C}$, and ${ }^{2}{ }^{2} \mathrm{U}$ also make significant contributions to dose Doses resulting from operation of the refabrication plant are generally less than those due to reprocessing and are dominated by release of ${ }^{220} \mathrm{Rn}$, lungs recelve the largest dose (38 mullirems)

A population of 15,000 , assumed to reside within $80 \mathrm{~km}$ of a mine and mill site near the Lemhi $\mathrm{P}_{\mathrm{dss}}$, receives a lung dose of 07 man rem due primarily to ${ }^{220} \mathrm{Rn}$ decay products The reprocessing and refabrication plants are located in a more populous region with an impacted population of $1,000,000$ Thyroid receives the highest total dose $(601$ man-rems) from the reprocessing plant releases, due primar1ly to ${ }^{3} \mathrm{H}$ and ${ }^{129} \mathrm{I}$ Lungs recerve the highest dose (26 man-rems) from refabrication plant releases, due to ${ }^{220} \mathrm{Rn}$ decay products

A need is established for ddditional information describing thorium ores and for site-specific meteorology for the mountanous areas in the western US where large deposits of thorum ores are found
\end{abstract}

\section{INTRODUCTION}

This report summarizes the information contaned in two recent publications which assess the radio$\log _{1 \mathrm{c} a l}$ environmental impact resulting from the mining and milling of thorium ore ${ }^{1}$ and from the reprocessIng and refabrication of thorium-uranium carbide fuel ${ }^{2}$ irradiated in a fast breeder reactor (FBR) The characteristics of thorium-uranium nuclear fuel systems are being examined for comparison with uraniumplutonium fuel systems as to their ability to breed fissionable material as well as comparing their resistance to diversion of nuclear material The potential resistance of thorium-uranium fuel materials to increasing

\footnotetext{
*Work performed under DOE/RRT AG 1020414 (OH 107) "Assessment of Advanced FBR Fuels"

†Metals and Ceramics Division

* Chemical Technology Division

$\S$ Health and Safety Research Division

IlConsultant
} 
proliferation of nuclear weapons is a subject of particular interest. Carbide fuels have several potential performance advantages in FBRs compared with oxide fuel, and this work is specifically concerned with carbide fuel in the ${ }^{232} \mathrm{Th} /{ }^{233} \mathrm{U}$ system.

The amount of thorium used in the United States is small and is currently obtained as a secondary product of the mining of minerals containing titanium and the rare earths. Power generation on a commercial scale using nuclear reactors fueled with thorium-based fuels will require a very large increase in the amount of thorium mined plus the reprocessing and refabrication of the spent fuel to recover the ${ }^{233} \mathrm{U}$ bred during irradiation of thorium in the reactor.

The information summarized here extends that resulting from other studies $3,4,5$ incorporates recently improved dose assessment methodology, and identifies the radioisotopes which are the principal contributors to the radiological environmental impact.

\section{METHODOLOGY}

Prediction of the impact of future ore mining and milling or spent fuel reprocessing operations in the absence of prior, full-scale commercial experience requires the preparation of a model of these operations, using flowsheets and mathematical formulas which permit the calculation of source terms (rates of release of various isotopes). Radiological doses may then be calculated by simulating the resulting interactions with the environment through contact or assimilation by vegetation or animals and, in particular, man.

Flowsheets were prepared to describe the movement of material through the various operations at a mine and mill complex and through reprocessing and refabrication plants. Radioactivity is released from each of these processes in the form of particles resulting from mechanical operations such as blasting or grinding. There is also a release of gases during chemical dissolution of spent fuel. Liquids, containing radioactivity, will also be released from the mill and the fuel refabrication plant. The source terms describing liquid, particulate, and gaseous release rates plus meteorology information were used as input to the AIRDOS-II computer code, ${ }^{6}$ which predicts the airborne distribution and deposition of the released radioactivity. Doses received by both the "fence-post man," who is assumed to be $1.6 \mathrm{~km}$ from the facility, and by the general population contained within an $80-\mathrm{km}$ radius of the facility are then calculated. The "fence-post man" is a hypothetical individual who lives just beyond the facility exclusion fence. Consumption of only locally grown food products was assumed for this individual; this is a conservative or doseincreasing assumption. Thus the dose calculated for this individual should be the maximum for a member of the general population. Population doses are based on consumption of both local and "imported" food products. The AIRDOS-II computer code, supplemented by the INREM-II computer code, also accounts for the differences in chemical and physical behavior of the various isotopes released, predicts the inhalation and ingestion of these isotopes by individuals at various distances from the facility, incorporates estimates of distributions within and elimination rates from the body, then uses such information to calculate doses to man.

There are a number of potential pathways of exposure to man from radioactive effluents released to the environment; these are illustrated schematically in Fig. 1. Radionuclides enter the environment from a facility via either liquid or atmospheric transport modes. They reach man through one or more collectors, with possible reconcentration by animals, crops, and aquatic biota. Pathways to human exposure include inhalation, ingestion, immersion in air, contamination of land surfaces, and submersion in water. An adaptation of the task group lung model ${ }^{7}$ is utilized to describe the dynamics of radionuclide retention within the respiratory tract. A catenary GI tract model based on the transit times recommended by Eve ${ }^{8}$ simulates retention in the GI tract. Retention in other organs is represented by multicompartment models consisting of series of decaying exponential terms. Detailed discussion of these models and assumptions is available in a report by Dunning et al. ${ }^{9}$ 
ORNL-DWG 79-18658

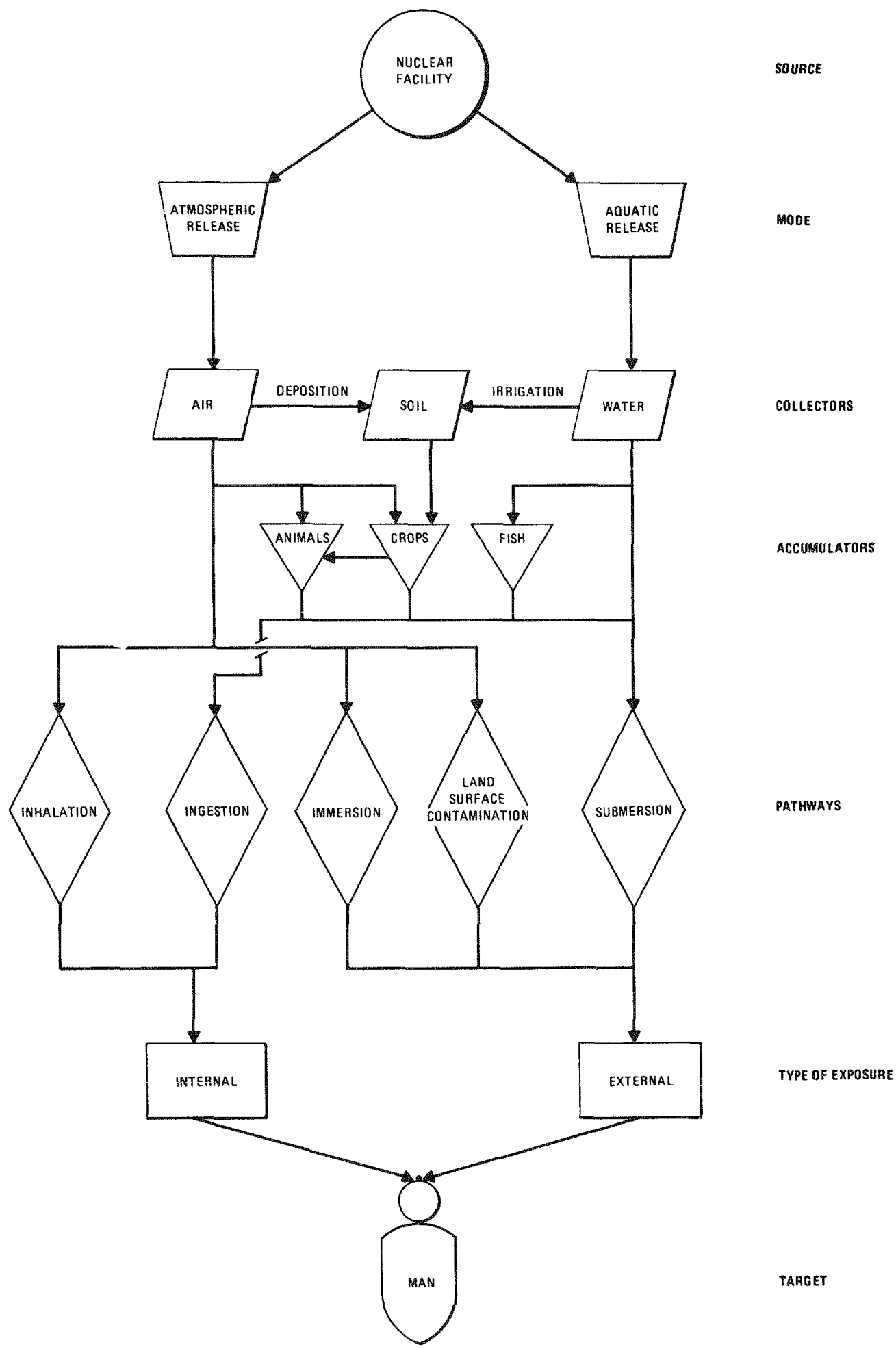

Fig. 1. Exposure pathways to man. 
Radiological impact is calculated as the 50-year dose commitment to individuals or populations in millirems or man-rems per year of facility operation. The dose commitment is calculated for a given intake of radionuclide and is defined as the total dose to a specific organ, resulting from a one-year intake or exposure, which will accrue during the remaining life time of the individual. Estimates of radiation dose to the total body and to major organs are considered for all pathways of internal exposure and are based on parameters applicable to the average adult. Population dose estimates are the sums of total-body or specificorgan doses to all individuals assumed living within $80 \mathrm{~km}$ of the facility.

\section{RADIOCHARACTERISTICS OF THORIUM AND DAUGHTERS}

Several characteristics of the ${ }^{232} \mathrm{Th}$ decay chain, shown in Fig. 2, result in noteworthy effects during and after processing of the thorium in ore or spent fuel. The decay products or daughters of ${ }^{22} \mathrm{Th}$ are a

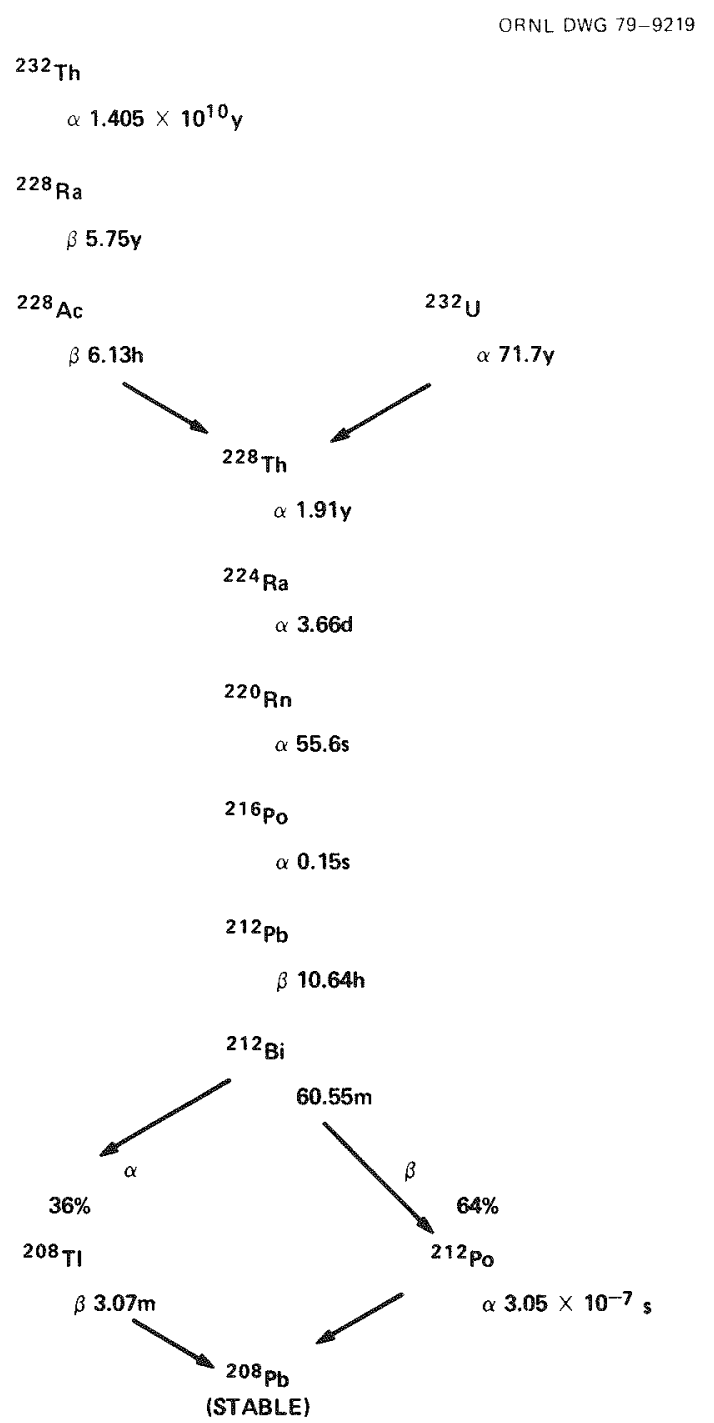

Fig. 2. Decay of ${ }^{232}$ Th and ${ }^{232} U$. 
mixture of alpha and beta emitters with some accompanying gamma radiation. The half-life of ${ }^{232} \mathrm{Th}$ (1.4E 10 years) is extremely long compared with its daughters; therefore, mass concentrations of the daughters in secular equilibrium with ${ }^{232} \mathrm{Th}$ are very low. One of the daughters, ${ }^{220} \mathrm{Rn}$, is a chemically inert gas with a short half-life $(56 \mathrm{sec})$. Gaseous ${ }^{220} \mathrm{Rn}$ is rapidly converted to other isotopes that are solid under normal conditions; therefore, a model which realistically predicts the behavior of any ${ }^{220} \mathrm{Rn}$ released to the environment must take this physical change into account.

Examination of the decay chain shows that the radioactivity of thorium chemically separated from its nonthorium daughters will be strongly influenced by the relatively short-lived ${ }^{228} \mathrm{Th}$, accompanied by a gradual buildup of ${ }^{228} \mathrm{Ra}$. Concurrently, the radioactivity of material from which most of the thorium has been removed will be controlled by the decay of ${ }^{228} \mathrm{Ra}$ as its concentration gradually declines to a level sustained by residual ${ }^{232} \mathrm{Th}$.

\section{MINING, MILLING, AND REFINING OF THORIUM}

\subsection{Description of Model Mine and Mill}

The locations and types of thorium deposits found in the United States are shown in Fig. 3 and in Tables 1 and 2. A substantial increase in demand for thorium would probably result in mining of the vein deposits located in the western United States. Two sites, one in the Lemhi Pass district of Idaho and Montana and the other in the Wet Mountains of Colorado, were selected for site-specific analysis in this study.

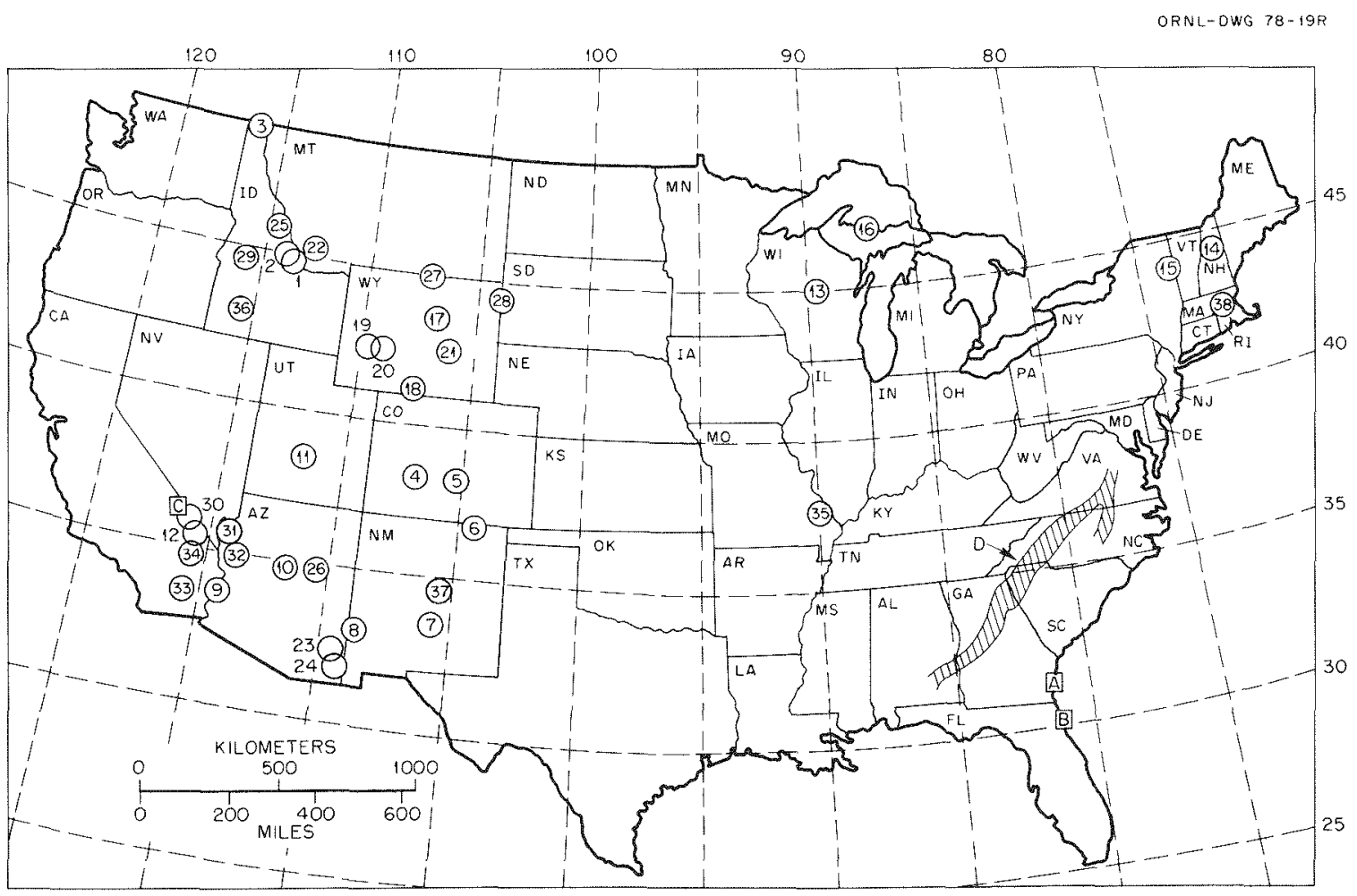

Fig. 3. Thorium resources in the United States. (Also see Tables 1 and 2 for legend.) 
Table 1. Vein thorium deposits - United States

\begin{tabular}{|c|c|c|c|c|c|c|c|c|c|}
\hline $\begin{array}{c}\text { Location } \\
\text { (see map in Fig. 3) }\end{array}$ & County, state & $\begin{array}{l}\text { Latitude } \\
\left({ }^{\circ} \mathrm{N}\right)\end{array}$ & $\begin{array}{l}\text { Longitude } \\
\qquad\left({ }^{\circ} \mathrm{W}\right)\end{array}$ & $\begin{array}{l}\text { Number of } \\
\text { samples }\end{array}$ & $\begin{array}{l}\text { Max } \\
\text { vein length } \\
(\mathrm{m})\end{array}$ & $\begin{array}{l}\text { Max } \\
\text { vein } \\
\text { thickness } \\
\text { (m) }\end{array}$ & $\begin{array}{c}\text { Thorium } \\
\text { content } \\
(\%)\end{array}$ & $\begin{array}{l}\text { Population } \\
\text { within } 80 \mathrm{~km} \\
\quad(1970)\end{array}$ & Ref. \\
\hline 1. Lemhi Pass & $\begin{array}{l}\text { Lemhi, ID } \\
\text { Beaver, MT }\end{array}$ & 44.93 & 113.5 & $200+$ & $1.2 \times 10^{3}$ & 9 & $0.001-16.3$ & 14,242 & $2-5$ \\
\hline $\begin{array}{l}\text { 2. Diamond } \\
\text { Creek }\end{array}$ & Lemhi, ID & 45 & 114 & 9 & $1.7 \times 10^{2}$ & 7.5 & $0.02-1.71$ & 7,364 & 3 \\
\hline 3. Hall Mt. & Boundary, ID & 48.99 & 116.38 & 14 & $2.1 \times 10^{2}$ & 4 & $0.01-21$ & 15,359 & 6 \\
\hline 4. Powderhorn & Gunnison, $\mathrm{CO}$ & 38.25 & 107 & $200+$ & $1.1 \times 10^{3}$ & 5.5 & $0.01-4.3$ & 32,192 & 7 \\
\hline 5. Wet Mts. & Custer, CO & 38.25 & 105.35 & $400+$ & $1.5 \times 10^{3}$ & 15 & $0.02-12.5$ & 262,144 & 8,9 \\
\hline 6. Laughlin Pk. & Colfax, NM & 36.75 & 104.25 & 10 & $2.4 \times 10^{2}$ & 6.1 & $0.05-0.82$ & 27,615 & 2 \\
\hline 7. Capitan Mts. & Lincoln, $\mathrm{NM}$ & 33.5 & 105.78 & 12 & 46 & 2.4 & $0.01-1.12$ & 47,668 & 10 \\
\hline 8. Gold Hill & Grant, NM & 33 & 109 & 2 & 12 & & $0.05-0.72$ & 39,900 & 2 \\
\hline 9. Quartzite & Yuma, AZ & 33.75 & 114.25 & 2 & 15 & 2.4 & $0.027-0.27$ & 22,613 & 2 \\
\hline 10. Cottonwood & Yavapai, AZ & 34.75 & 112 & 1 & 30 & 18 & $0.013-0.91$ & 64,769 & 2 \\
\hline $\begin{array}{l}\text { 11. Monroe } \\
\text { Canyon }\end{array}$ & Seiver, UT & 38.58 & 112 & 1 & 7.6 & 15 & $0.18-0.29$ & 19,868 & 2 \\
\hline $\begin{array}{l}\text { 12. Mountain } \\
\text { Pass }\end{array}$ & San Bernardino, CA & 35.46 & 115.5 & 18 & $4.9 \times 10^{2}$ & 3 & $0.02-4.9$ & 30,321 & 11 \\
\hline 13. Wausau & Marathon, WI & 45 & 89.5 & 20 & $4.6 \times 10^{2}$ & 0.5 & & 338,408 & 12 \\
\hline
\end{tabular}


Table 2. Other thorium deposits - United States

\begin{tabular}{|c|c|c|c|c|c|c|}
\hline $\begin{array}{c}\text { Location } \\
\text { (see map in Fig 3) }\end{array}$ & County, state & $\begin{array}{l}\text { Latitude } \\
(\mathrm{N})\end{array}$ & $\begin{array}{l}\text { Longitude } \\
\left({ }^{\circ} \mathrm{W}\right)\end{array}$ & $\begin{array}{l}\text { Thorium content } \\
\text { (ppm) }\end{array}$ & $\begin{array}{l}\text { Population } \\
\text { w1thin } 80 \mathrm{~km} \\
\text { (1970) }\end{array}$ & Ref \\
\hline 14 Conway & Conway, $\mathrm{NH}$ & 4400 & 7116 & 64 & & 29 \\
\hline 15 Mineville & Essex, NY & 4416 & 7358 & $100-3800$ & & 30 \\
\hline 16 Palmer & Marquette, MI & 465 & 875 & 50,000 & & 31 \\
\hline 17 Owl Creek & Hot Spring, WY & 4348 & 10550 & 134 & 30,292 & 13,14 \\
\hline 18 Rawlings uplift & Carbon, $W Y$ & 4178 & 10713 & 146 & 13,201 & 13,14 \\
\hline 19 Wind River & I remont, WY & 435 & 1095 & 366 & 31,648 & 13,14 \\
\hline 20 Wind River & Fremont, WY & 435 & 1096 & 66 & 31,648 & 13,14 \\
\hline 21 Seminoe & Natrona, WY & 4247 & 10675 & $194-273$ & 51,995 & 13,14 \\
\hline 22 Deer Creek & MT & 452 & 1125 & & & 30 \\
\hline 23 Blue $\mathrm{Mt}$ & Greenlee, $\mathrm{AZ}$ & 3255 & 10920 & 40 & 30,481 & 13,15 \\
\hline 24 Dos Cabesas & Coch1se, AZ & 322 & 10942 & 19 & 30,098 & 13,15 \\
\hline 25 Mineral H1ll & Lemh1, ID & 456 & 1149 & & & 13,15 \\
\hline 26 Dramond Rim & Gila, AZ & 3425 & 11108 & 24 & 10,416 & 13,15 \\
\hline 27 Little Big Horn & Big Horn, WY & 4466 & 106,95 & & & \\
\hline 28 Bear Lodge & Crook, WY & 445 & 10433 & $400-2500$ & & 30 \\
\hline 29 Idaho & Idaho, ID & 46 & 115 & 200 & & 32 \\
\hline 30 McCullough Mt & Clark, NV & 36 & 116 & $55-283$ & 145,059 & 13,15 \\
\hline 31 Black Mts & Mohave, $\mathrm{AZ}$ & 355 & 1145 & $180-253$ & 137,958 & 13,15 \\
\hline 32 S Peacock Mts & Mohave, $\mathrm{AZ}$ & 35 & 114 & $37-153$ & 137,958 & 13,15 \\
\hline 33 Big Maria Mts & Riverside, CA & 335 & 116 & $29-146$ & 136,470 & 13,15 \\
\hline 34 Marble Mts & San Bernardino, CA & 35 & 116 & $75-148$ & 136,470 & 13,15 \\
\hline 35 St Francois Mts & St Trancols, MO & 375 & 90 & 47 & 320,378 & 13,17 \\
\hline 36 Idaho Batholith & Boise, ID & 440 & 11590 & 100 & & 32 \\
\hline 37 Gallınas & Lincoln, NM & 3415 & 10563 & & & 33 \\
\hline 38 Worcester & Worcester, MA & 4225 & 7175 & 300 & & 30 \\
\hline A Georgid & Charlton, GA & 32 & 816 & $<1000$ & & 34 \\
\hline B Florida & Nassau, $\Gamma \mathrm{L}$ & 302 & 813 & $<1000$ & & 34 \\
\hline C Calıfornid & San Bernardino, CA & 36 & 117 & $200-5000$ & & 30 \\
\hline D Piedmont District & $\mathrm{VA}, \mathrm{NC}, \mathrm{SC}, \mathrm{AL}$ & $32-38$ & $78-87$ & {$[567 \%]$} & & 30 \\
\hline
\end{tabular}

Vein locations are found by using sensitive instruments to detect the radioactivity of thorium daughters Bulldozers have been used to remove the overburden and expose the venns An aenal view of several prospects in the Lemhi Pass district is shown in Fig 4

The principal components of a mine and mill complex include open-pit mine, ore storage pile, mill, tallings impoundment, and thorium refinery The ore ple will contain a 60-day reserve to allow operation of the mill at its $1600-\mathrm{Mg} /$ day capacity during those winter months when the weather stops mining activities at the higher elevations Several characteristics of the mine, mill, and refinery are listed in Table 3

After removing the overburden at the mine site, the exposed vein(s) of thorium-bearing ore would be broken up by bulldozers, dozer-rippers, and selective blastıng Front-end loaders are used to load trucks for transport to the ore storage pile at the mill The sequence for processing ore at the mill and recovery of the thorium is shown in Fig 5 The flowsheet is based on experiments performed by the US Bureau of Mines ${ }^{10,11}$ The crude $\mathrm{Th}\left(\mathrm{CO}_{3}\right)_{2}$ product from the mill is purified to produce reactor-grade $\operatorname{Th}\left(\mathrm{NO}_{3}\right)_{4}$ $\cdot 4 \mathrm{H}_{2} \mathrm{O}$, using a flowsheet ${ }^{12}$ developed for processing irradiated $\mathrm{ThO}_{2}$ and described in $\mathrm{Fig} 6$ Mass and volumetric flow rates for key process streams in the mill and refinery are given in Table 4 The leached and washed solid wastes from the mil are transferred as a slurry to a tallings pond where the solids separate out and are eventually allowed to dry About $9 \%$ of the thorium orignally contaned in the ore and essentially all of the daughter activity are deposited in the tailngs pond Some ${ }^{220} \mathrm{Rn}$ gas is released at the mine and 


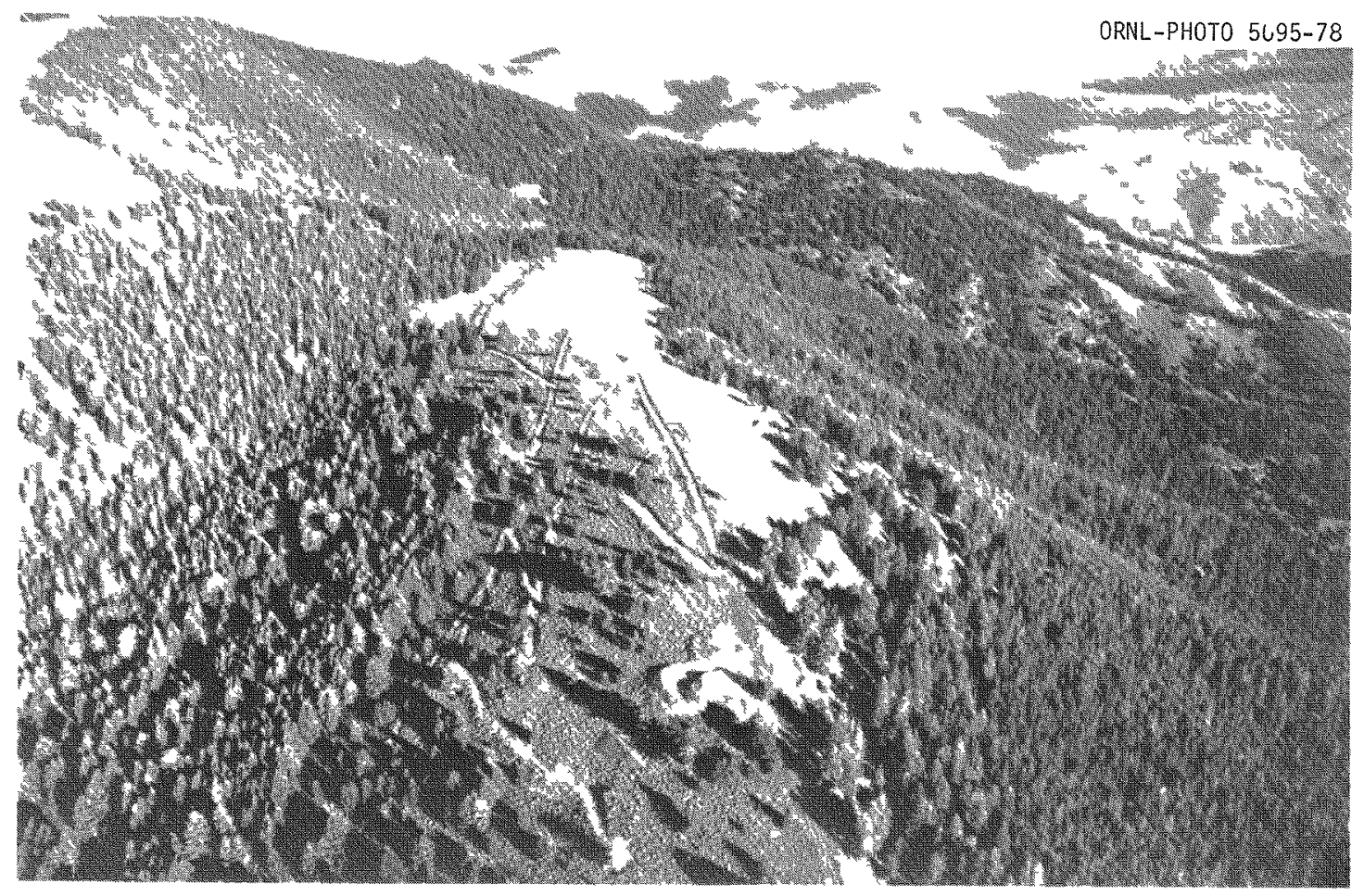

Fig. 4. Lemh Pass exploratory trenches.

Table 3 Characteristics of the open pit thorum mme and the model thorium mill and refinery

\begin{tabular}{|c|c|c|}
\hline \multicolumn{3}{|l|}{ 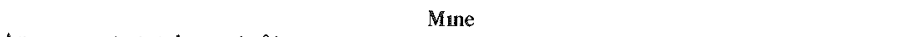 } \\
\hline Approximate total ared $\left(\mathrm{m}^{2}\right)$ & & $49 \mathrm{E} 4^{a}$ \\
\hline Exposed thorrum bearing vein(s) $\left(\mathrm{m}^{2}\right)$ & & $12 E 4$ \\
\hline Ore production $(\mathrm{Mg} / \mathrm{d} d \mathrm{y})$ & & 1600 \\
\hline Average thorium content ( $\% \mathrm{ThO}_{2}$ equivalent) & & 05 \\
\hline Water dramage $\left(\mathrm{m}^{3} /\right.$ day $)$ & & $68 \mathrm{E} 2$ \\
\hline Average depth $(\mathrm{m})$ & & 23 \\
\hline \multicolumn{3}{|c|}{ Mill and refunery } \\
\hline Ore capacity (Mg/day) & & 1600 \\
\hline Days of operdtion annually & & 300 \\
\hline \multicolumn{3}{|l|}{ Thorium recovery efficiency $(\%)$} \\
\hline Mill & & 91 \\
\hline Refinery & & 995 \\
\hline $\mathrm{Th}\left(\mathrm{NO}_{3}\right)_{4} 4 \mathrm{H}$ O production $(\mathrm{Gg} /$ year $)$ & & 45 \\
\hline Water required $\left(\mathrm{m}^{3} /\right.$ day $)$ & & $24 \mathrm{~F} 3$ \\
\hline Ore pule $(\mathrm{m})$ & & $100 \times 32 \times 15$ \\
\hline$(\mathrm{Gg})$ & & 96 \\
\hline Aur discharge from complex $\left(\mathrm{m}^{3} / \mathrm{sec}\right)$ & & 113 \\
\hline \multicolumn{3}{|l|}{ Filter losses (\%) } \\
\hline Crusher dust & & 07 \\
\hline $\begin{array}{l}\mathrm{Th}\left(\mathrm{NO}_{3}\right)_{4} 4 \mathrm{H}_{2} \mathrm{O} \text { product line } \\
\text { (bags plus HFPA) }\end{array}$ & & 005 \\
\hline \multicolumn{3}{|c|}{ Tallngs umpoundment } \\
\hline & Montana & Colorado \\
\hline \multicolumn{3}{|l|}{$\begin{array}{l}\text { Average ared durmg } 20 \text { year mill } \\
\text { life }\left(\mathrm{m}^{2}\right)\end{array}$} \\
\hline Dry beack & $4 \mathrm{E} 3$ & $36 \mathrm{E} 3$ \\
\hline Pond & $57 \mathrm{E} 5$ & $49 \mathrm{E} 5$ \\
\hline \multicolumn{3}{|l|}{$\begin{array}{l}\text { Average area exposed during post mill } \\
\text { life }\left(\mathrm{m}^{2}\right)\end{array}$} \\
\hline Dry beach & $4 \mathrm{E} 3$ & $4 \mathrm{E} 3$ \\
\hline Pond & $38 \mathrm{E} 5$ & $27 \mathrm{E} 5$ \\
\hline
\end{tabular}




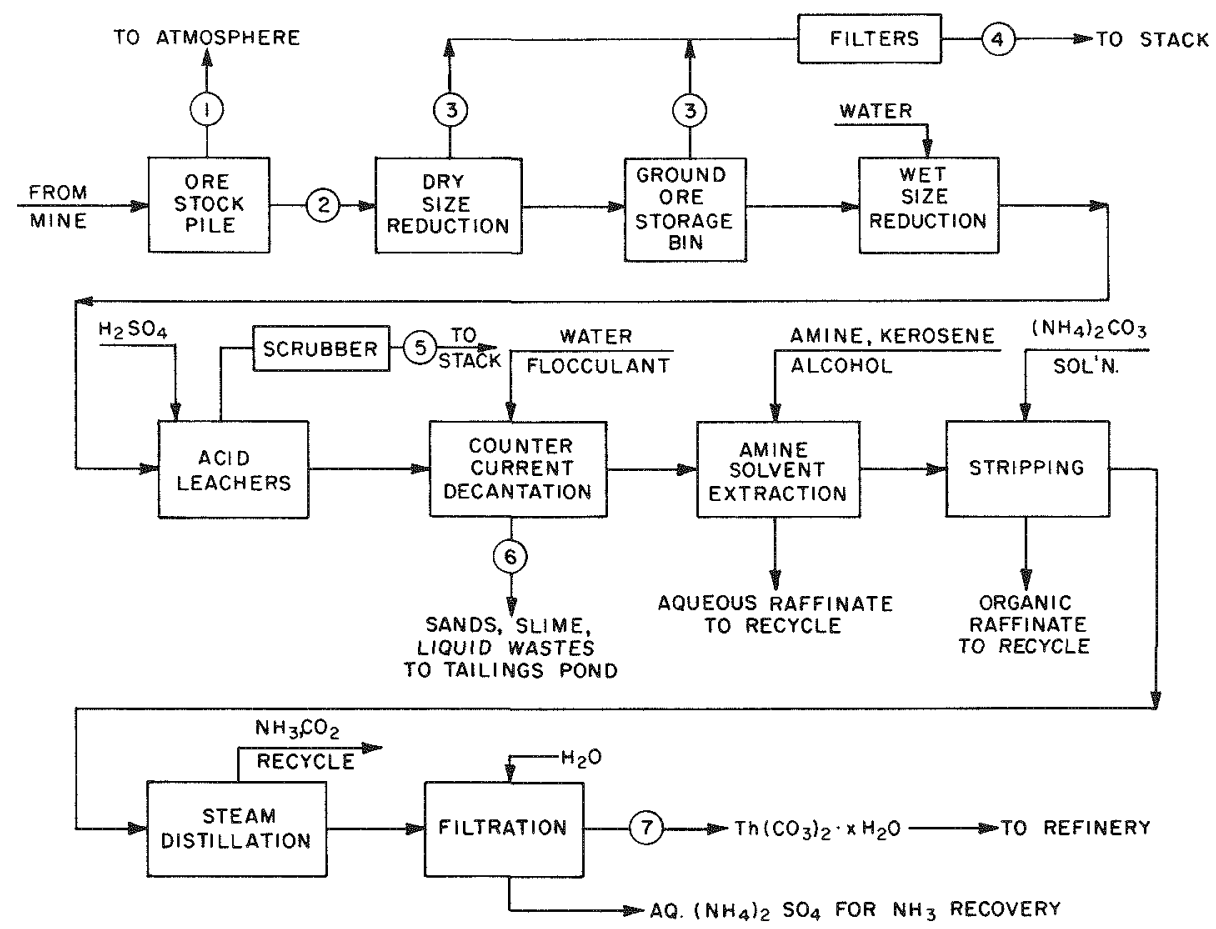

Fig. 5. Conceptual thorium milling, flow diagram.

TO RECYCLE

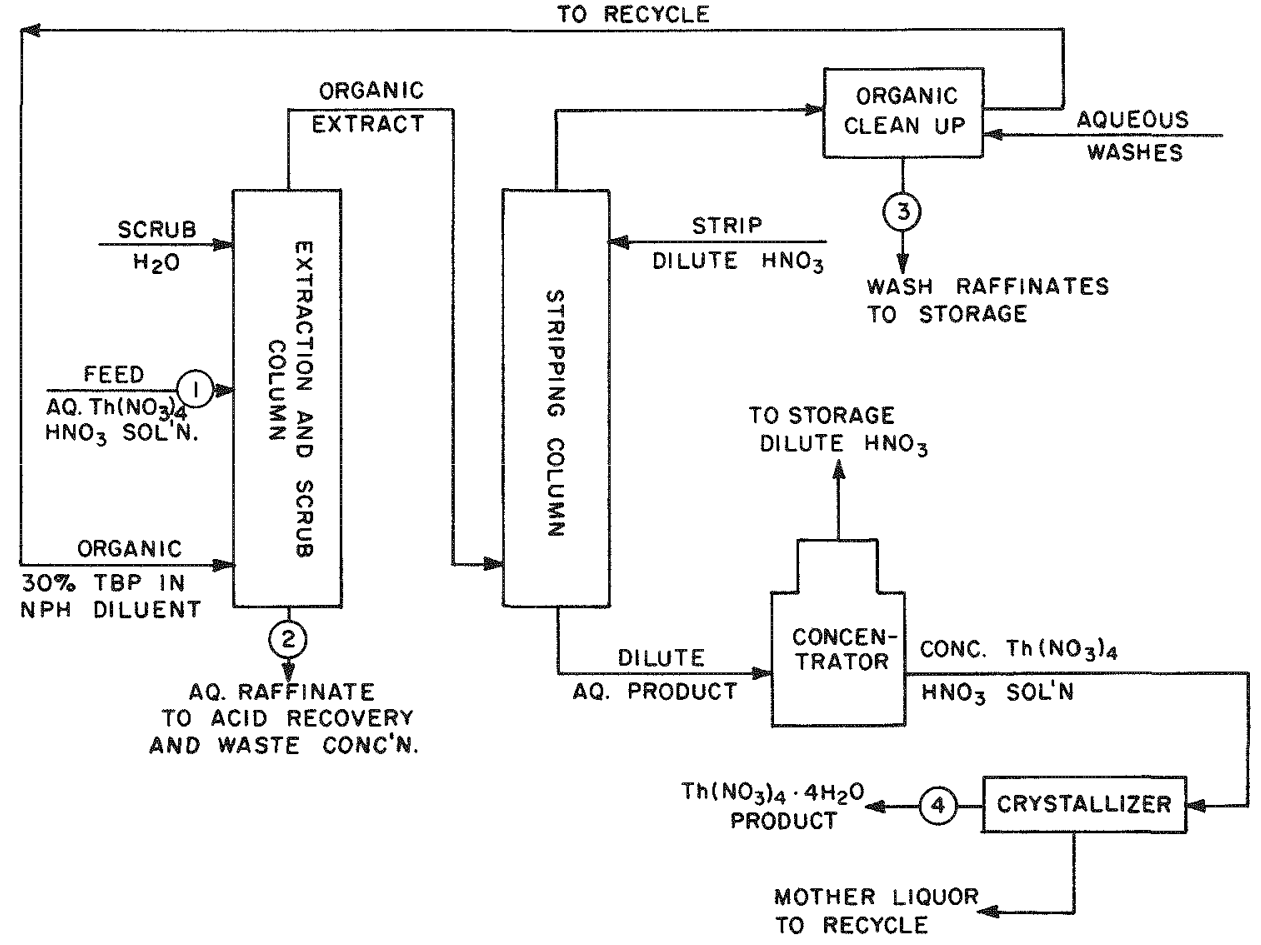

Fig. 6. Conceptual thorium refining, flow diagram. 
Table 4. Mass and volume flow rates for principal process streams of the model mill and refinery

\begin{tabular}{|c|c|c|c|c|c|c|}
\hline & \multicolumn{3}{|c|}{ Mill } & \multicolumn{3}{|c|}{ Refinery } \\
\hline & Feed $^{a}$ & Product & Tailings & Feed & $\begin{array}{c}\text { ThNT } \\
\text { product }\end{array}$ & $\begin{array}{c}\text { Aqueous } \\
\text { wastes }\end{array}$ \\
\hline $\begin{array}{l}\text { Thorium } \\
\mathrm{kg} / \mathrm{sec} \\
(\mathrm{kg} / \text { day })\end{array}$ & $\begin{array}{c}8.14 \mathrm{E}-2^{b} \\
(7.03 \mathrm{E}+3)\end{array}$ & $\begin{array}{c}7.41 \mathrm{E}-2 \\
(6.40 \mathrm{E}+3)\end{array}$ & $\begin{array}{c}7.33 \mathrm{E}-3 \\
(6.33 \mathrm{E}+2)\end{array}$ & $\begin{array}{c}7.41 \mathrm{E}-2 \\
(6.40 \mathrm{E}+3)\end{array}$ & $\begin{array}{c}7.37 \mathrm{E}-2 \\
(6.37 \mathrm{E}+3)\end{array}$ & $\begin{array}{c}3.70 \mathrm{E}-3 \\
(3.20 \mathrm{E}+2)\end{array}$ \\
\hline $\begin{array}{l}\text { Volume } \\
\mathrm{m}^{3} / \mathrm{sec} \\
\left(\mathrm{ft}^{3} / \text { day }\right)\end{array}$ & $\begin{array}{c}3.47 \mathrm{E}-2 \\
(1.06 \mathrm{E}+5)\end{array}$ & $\begin{array}{l}d \\
d\end{array}$ & $\begin{array}{c}3.47 \mathrm{E}-2 \\
(1.06 \mathrm{E}+5)\end{array}$ & $\begin{array}{c}4.06 \mathrm{E}-4 \\
(1.24 \mathrm{E}+3)\end{array}$ & $\begin{array}{l}d \\
d\end{array}$ & $\begin{array}{c}3.11 \mathrm{E}-3 \\
(9.50 \mathrm{E}+3)\end{array}$ \\
\hline
\end{tabular}

${ }^{a}$ Feed rate of ore is $18.5 \mathrm{~kg} / \mathrm{sec}(1.6 \mathrm{Gg} /$ day $)$.

$b_{\text {Read as }} 8.14 \times 10^{-2}$.

${ }^{c}$ Includes both process liquids and solids.

$d_{\text {Not determined. }}$

during crushing and acid leaching of the ore in the mill; ${ }^{220} \mathrm{Rn}$ is continuously regenerated from decay of ${ }^{224} \mathrm{Ra}$.

\subsection{Source Terms from Mining, Milling, and Refining}

\subsubsection{Mining}

Radioactivity will be released to the environment as gas and dust as a result of mining operations. As in ERDA-1541 it is assumed that 3 acres of thorium-bearing ore containing the equivalent of $0.5 \% \mathrm{ThO}_{2}$ are exposed in one or more pits being worked to supply $1600 \mathrm{Mg} /$ day of ore to the mill. ${ }^{13}$ In the absence of information on release of ${ }^{220} \mathrm{Rn}$ from thorium ore, a mechanism similar to that for release of ${ }^{222} \mathrm{Rn}$ from uranium ore was assumed. ${ }^{13,14}$ An expression for ${ }^{220} \mathrm{Rn}$ flux, $J_{0}$, was developed:

$$
J_{0}=455 \rho(k / p)^{1 / 2}
$$

where

$$
\begin{aligned}
& \rho=\text { bulk density of the ore, } \mathrm{kg} / \mathrm{m}^{3}, \\
& k=\text { effective diffusion coefficient for }{ }^{220} \mathrm{Rn} \text { in ore, } \mathrm{m} / \mathrm{sec}, \\
& p=\text { void fraction in ore. }
\end{aligned}
$$

A flux rate was calculated for ${ }^{220} \mathrm{Rn}$ of $1.32 \mathrm{kBq} / \mathrm{m}^{2} \cdot \mathrm{sec}$ or a total of $16 \mathrm{MBq} / \mathrm{sec}(0.43 \mathrm{mCi} / \mathrm{sec})$ from $3700 \mathrm{~m}^{2}$ ( 3 acres) of exposed ore. 1

A number of activities at the mine will inject dust in to the air. These include dozing, selective blasting, loading ore into trucks, and movement of vehicles. Information on which to make a quantitative determination of the amount of fugitive dust generated is limited. The dust raised by vehicular traffic was calculated using the results of a study done for the Environmental Protection Agency. ${ }^{15}$ The amount of dust generated by other mining activities was also estimated. The expected dampness of the ore plus routine sprin- 
kling of the mine area with water controls the amount of dust released The estimated radioactivity contained in the fugitive dust is shown in Table 5

\section{Milling and refining}

Loading of ore and movement from the ore storage ple to the mill will generate arrborne particulate contamination The method used for calculation of the amount of dust suspended was as above ${ }^{15}$ The amount of radioactivity contained in dust from ore handling at the mill is shown in Table 6

Table 5. Radioactivity contained in dust generated by mining operations

\begin{tabular}{lccc}
\hline \multirow{2}{*}{ Isotope } & \multicolumn{3}{c}{ Rddioactivity $[\mathrm{Bq}(\mathrm{pCl})]^{a}$} \\
\cline { 2 - 4 } & Perg of ore & $\operatorname{Per} 13 \mathrm{~kg}(29 \mathrm{lb})$ dust $^{b} /$ day \\
\hline $232 \mathrm{Th}$ & $18(48 \mathrm{E} 2)^{c}$ & $12 \mathrm{E} 5$ & $(32 \mathrm{E} 6)$ \\
$228 \mathrm{Ra}$ & $18(48 \mathrm{E} 2)$ & $12 \mathrm{E} 5$ & $(32 \mathrm{E} 6)$ \\
$228 \mathrm{Ac}$ & $18(48 \mathrm{E} 2)$ & $12 \mathrm{E} 5$ & (3 2E6) \\
$228 \mathrm{Th}$ & $18(48 \mathrm{E} 2)$ & $12 \mathrm{E} 5$ & $(32 \mathrm{E} 6)$ \\
$22{ }^{2} \mathrm{Ra}$ & $18(48 \mathrm{E} 2)$ & $12 \mathrm{E} 5$ & $(32 \mathrm{E} 6)$ \\
$22{ }^{2} \mathrm{Rn}$ & $18(48 \mathrm{E} 2)$ & $12 \mathrm{E} 5$ & $(32 \mathrm{E} 6)$ \\
$216 \mathrm{Po}$ & $18(48 \mathrm{E} 2)$ & $12 \mathrm{E} 5$ & $(32 \mathrm{E} 6)$ \\
$212 \mathrm{~Pb}$ & $18(48 \mathrm{E} 2)$ & $12 \mathrm{E} 5$ & $(32 \mathrm{E} 6)$ \\
$212 \mathrm{Bi}$ & $18(48 \mathrm{E} 2)$ & $12 \mathrm{E} 5$ & $(32 \mathrm{E} 6)$ \\
$212 \mathrm{Po}$ & $11(31 \mathrm{E} 2)$ & $75 \mathrm{E} 4$ & $(20 \mathrm{E} 6)$ \\
$228 \mathrm{Tl}$ & $6(17 \mathrm{E} 2)$ & $42 \mathrm{E} 4$ & $(11 \mathrm{E} 6)$ \\
& & &
\end{tabular}

$a_{1} \mathrm{~Bq}=27 \mathrm{pCl}$

${ }^{b}$ Concentration of Th in fugitive dust is diluted by dust containing no Th to about half that of the ore

$c_{4} 8 \mathrm{E} 2=48 \times 10^{2}$

Table 6 Estimated source terms for operation and closing of the model mill

\begin{tabular}{|c|c|c|c|c|c|c|}
\hline \multirow{3}{*}{ Nuclide } & \multicolumn{6}{|c|}{ Source term $(\mathrm{Bq} / \mathrm{sec})^{a}$} \\
\hline & \multirow{2}{*}{$\begin{array}{c}\text { Ore } \\
\text { handling }\end{array}$} & \multirow{2}{*}{$\begin{array}{c}\text { Mill } \\
+ \\
\text { refinery }\end{array}$} & \multicolumn{2}{|c|}{$\begin{array}{l}\text { Tallings beach } \\
\text { and pond }\end{array}$} & \multicolumn{2}{|c|}{$\begin{array}{l}\text { Covering dry } \\
\text { tailings }\end{array}$} \\
\hline & & & Montana & Colorado & Montana & Colorado \\
\hline${ }^{232} \mathrm{Th}$ & 052 & 018 & 0037 & 033 & 037 & 037 \\
\hline${ }^{228} \mathrm{Ra}$ & 052 & 018 & 033 & 30 & 33 & 33 \\
\hline${ }^{228} \mathrm{AC}$ & 052 & 018 & 033 & 30 & 33 & 33 \\
\hline${ }^{228} \mathrm{Th}$ & 052 & 018 & 026 & 22 & 24 & 24 \\
\hline${ }^{224} \mathrm{Ra}$ & 052 & 018 & 026 & 22 & 24 & 24 \\
\hline${ }^{216} \mathrm{Po}$ & 052 & 018 & 026 & 22 & 24 & 24 \\
\hline${ }^{212} \mathrm{~B} 1$ & 052 & 018 & 026 & 22 & 24 & 24 \\
\hline $212 \mathrm{~Pb}$ & 052 & 018 & 026 & 22 & 24 & 24 \\
\hline $208 \mathrm{Tl}$ & 018 & 007 & 009 & 08 & 08 & 08 \\
\hline${ }^{2}+2 \mathrm{Po}$ & 033 & 011 & 018 & 14 & 16 & 16 \\
\hline${ }^{220} \mathrm{Rn}$ & $15 \mathrm{E} 7^{b}$ & $36 \mathrm{E} 7$ & $12 \mathrm{E} 7$ & $16 \mathrm{E} 7$ & $11 \mathrm{E} 7$ & $93 \mathrm{E} 6$ \\
\hline
\end{tabular}

$a_{1 \mathrm{~Bq}} / \mathrm{sec}=27 \mathrm{pCl} / \mathrm{sec}$

$b_{1} 5 \mathrm{E} 7=15 \times 10^{7}$ 
Mechanical conditioning of the ore within the mill, such as crushing and grinding, and packaging of the refined $\mathrm{Th}\left(\mathrm{NO}_{3}\right)_{4} \cdot 4 \mathrm{H}_{2} \mathrm{O}$ product will introduce dust into the process ventilation system. A similarity of behavior of thorium materials to uranium ore and uranium yellow cake was assumed for calculation of particulate releases from the mill and refinery. ${ }^{16,17}$ If $0.008 \%$ of the ore processed becomes entrained in the process off-gas ${ }^{3}$ and is carried to bag filters with a removal efficiency of $99.3 \%$, then $5.6 \mathrm{E}-7$ of the total ore treated will be released to the environment. Concurrently, an estimated $1.25 \%$ of the $\left.\mathrm{Th}_{(\mathrm{NO}}\right)_{4} \cdot 4 \mathrm{H}_{2} \mathrm{O}$ product becomes airborne during packaging and is carried to the filters. ${ }^{16}$ The combined efficiency of the bag filters (99.3\%) and the high-efficiency particulate air (HEPA) filters (99.95) allows only 4.4E-8 of the $\mathrm{Th}\left(\mathrm{NO}_{3}\right)_{4} \cdot 4 \mathrm{H}_{2} \mathrm{O}$ processed to escape to the environment. The radioactivity associated with the ${ }^{232} \mathrm{Th}$ and its daughters contained in dust released from the mill and refinery is given in Table 6 . Wind blowing on the ore storage pile will also contribute to particulate release, but this term was not calculated because an adequate model for this process was not available.

Radon-220 released from ore in storage and during the acid leaching treatment also contributes to the airborne radioactivity. Release of ${ }^{220} \mathrm{Rn}$ from the ore storage pile was calculated assuming a surface area of $7160 \mathrm{~m}^{2}$ and a value for $\mathrm{kp}^{-1}=5 \mathrm{E}-6 \mathrm{~m}^{2} / \mathrm{sec}$ (comparable to coarse sand) in the equation given in Sect. 4.2 .1 , yielding a rate of $14.6 \mathrm{MBq} / \mathrm{sec}$. Radon-220 is continuously generated from ${ }^{224} \mathrm{Ra}$ decay and is released to the off-gas system during the 12 -hr acid leaching of the ore. This contribution of ${ }^{220} \mathrm{Rn}, 36$ $\mathrm{MBq} / \mathrm{sec}$, was calculated from the equation

$$
{ }^{220} \mathrm{Rn}=C_{\mathrm{Rn}} \cdot \lambda_{220} \cdot t \cdot w \cdot f
$$

where

$$
\begin{aligned}
C_{\mathrm{Rn}} & =\text { concentration of }{ }^{220} \mathrm{Rn} \text { in secular equilibrium, } 17.7 \mathrm{kBq} / \mathrm{kg} \text { ore, } \\
\lambda_{220} & =\text { decay constant for }{ }^{220} \mathrm{Rn}, 0.0125 / \mathrm{sec}, \\
t & =\text { leaching time, } 4.32 \mathrm{E} 4 \mathrm{sec}, \\
w & =\text { mass of ore processed per day, } 1600 \mathrm{Mg}(18.5 \mathrm{~kg} / \mathrm{sec}), \\
f & =\text { factor correcting for decay of }{ }^{220} \mathrm{Rn} \text { between generation and release, } 0.2 \text { (ERDA, 1976). }
\end{aligned}
$$

Technology is available to increase the holdup time of the ${ }^{220} \mathrm{Rn}$ and thus allow decay to any level justified by a cost-benefit analysis.

The tailings impoundment is also a source of airborne contamination in the form of particles and gas during and after mill operation. Wind acting on exposed tailings solids will pick up small particles, while $224 \mathrm{Ra}$ dissolved in the liquid portions of the tailings and contained in exposed solids will provide a flux of ${ }^{220} \mathrm{Rn}$ gas. Very little of the rapidly decaying ${ }^{220} \mathrm{Rn}\left(\mathrm{T}_{1 / 2}=55.6 \mathrm{sec}\right)$ released from solids covered by a shallow layer of water will reach the atmosphere. Radon-220 flux from the exposed tailings and the pond surface were calculated using Eq. (1), with the following results:

$J_{0}$ (exposed tailings) $=1.67 \mathrm{kBq} / \mathrm{m}^{2} \cdot \mathrm{sec}$,

$J_{0}($ pond $)=19.3 \mathrm{~Bq} / \mathrm{m}^{2} \cdot \mathrm{sec}$.

Particles will be blown from any exposed tailings beach. During mill operation the tailings will be kept wet or treated chemically to minimize the blowing of particles, but these precautions are not completely 
effective The flux for tdilings solids which become suspended by wind was calculated using a model based on the phenomenon of saltation, ${ }^{18}$ that 1 , the suspension of small particles $(<80 \mu \mathrm{m})$ following impact by larger particles blown across the beach surface The total amount of suspended particles depends on the surface area of tailings beach exposed to wind action during and after the operating life of the mill

A model was selected ${ }^{11}$ that accounted for an assumed geometry for the tallngs impoundment, the rates at which tailings solids and liquid are supplied, wind velocities, and the net rates of evaporation at the Lemhi Pass and Wet Mountans sites The area of talings beach and pond during and after mill life was used to determine the ${ }^{220} \mathrm{Rn}$ source terms given in Table 7 and the particulate radioactivity shown in Table 6

Table 7 Source terms for ${ }^{2}{ }^{\circ} \mathrm{Rn}$ during mill operating life and during final evaporation of the pond and covering of the dry tallings after the mill is closed

\begin{tabular}{|c|c|c|c|c|c|}
\hline \multirow{2}{*}{ Hypothetical location } & \multirow{2}{*}{$\begin{array}{c}\text { Area of } \\
\text { dry tallings } \\
\left(\mathrm{m}^{2} \times \mathrm{E} 2\right)\end{array}$} & \multirow{2}{*}{$\begin{array}{c}\text { Area of } \\
\text { pond } \\
\left(\mathrm{m}^{2} \times \mathrm{E} 4\right)\end{array}$} & \multicolumn{3}{|c|}{ Source term $(\mathrm{Bq} / \mathrm{sec} \times \mathrm{E} 5)^{a}$} \\
\hline & & & Dry tallngs & Pond & Total \\
\hline \multicolumn{6}{|l|}{ Montana } \\
\hline Mill operating life & $4^{b}$ & 57 & 7 & 110 & 117 \\
\hline $\begin{array}{l}\text { Evaporation of pond and } \\
\text { covering of tailings }\end{array}$ & 40 & 38 & $40^{c}$ & 73 & 113 \\
\hline \multicolumn{6}{|l|}{ Colorado } \\
\hline Mill operatıng lıfe & 36 & 49 & 60 & 95 & 155 \\
\hline $\begin{array}{l}\text { Evaporation of pond and } \\
\text { covering of talings }\end{array}$ & 40 & 27 & $40^{c}$ & 52 & 92 \\
\hline
\end{tabular}

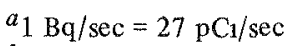

${ }^{b}$ Read as $4 \times 10^{2} \mathrm{~m}^{2}$

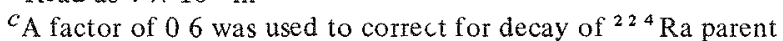

The requirements for long-term stabilization of the tailings from a thorium mill are much less demandIng than those for a uranium mill In principle, $03 \mathrm{~m}$ of earth cover will reduce the ${ }^{220} \mathrm{Rn}$ released to $2 \mathrm{E}-8$ of that emanated and, concurrently, essentially eliminate arborne radioactive particles Since the longestlived daughter in the ${ }^{232} \mathrm{Th}$ decay cham is ${ }^{228} \mathrm{Ra}\left(t_{1 / 2}=575\right.$ years $)$, after about 60 years the tallngs impoundment will be equivalent to an ore body contanning about $005 \%$ thorium oxide It would take much longer for uranium tallings to decay to a comparable level because of the longer-lived ${ }^{226} \mathrm{Ra}\left(t_{1 / 2}=\right.$ 1622 years)

\subsection{Radiological Impact}

Population data for dose calculations were obtamed from the "Reactor Site Population Analysis"19 computer code avalable at Oak Ridge National Laboratory Output from this code is based on the U.S 1970 census. The best avalable meteorological data for both the Lemb1 Pass and the Wet Mountains sites were obtaned from the National Oceanic and Atmosphenc Administration for a pair of first-order weather stations located near each site Meteorological towers are being installed at potential mine and mill sites in the Lemhi Pass area to obtain additional site-specific weather data for use in later studies The following discussions of radiological impact focuses on the Lemh1 Pass area 


\subsubsection{Maximum individual doses}

The maximum individual doses at $1.6 \mathrm{~km}$ from the mill site are shown in Table 8. Lung is the critical organ, receiving a dose commitment of 35.3 millirems, while doses of 9.5 and 2.4 millirems are delivered to bone and total body respectively.

Table 9 is a breakdown of dose by radionuclides to various organs. Radon- 220 and daughters are the primary contributors to all organs. Second in importance is ${ }^{228} \mathrm{Ra}$, delivering $36 \%$ of the dose to total body and thyroid. The contribution of various exposure pathways to the dose commitment to total body, bone, and lungs is shown in Table 9 . Ingestion is the primary mode of exposure for total body (47\%) and bone $(61 \%)$, while inhalation contributes $99 \%$ of the dose to lungs.

Additional AIRDOS-II computer runs were made to determine the increase in dose commitment if the site boundary were located $0.8 \mathrm{~km}$ from the point of release of radionuclides, instead of $1.6 \mathrm{~km}$ as assumed above. It was determined that the maximum individual dose would increase by a factor of approximately

Table 8. Maximum individual 50-year dose commitment to total body and various organs from radioactivity released to the atmosphere during one year of facility operation

\begin{tabular}{|c|c|c|c|c|c|c|c|}
\hline \multirow{2}{*}{ Meteorology } & \multicolumn{7}{|c|}{ Dose commitment (millirems) } \\
\hline & Total body & GI tract & Bone & Thyroid & Lungs & Kidneys & Liver \\
\hline \multicolumn{8}{|c|}{ Lemhi Pass site } \\
\hline Butte & 2.4 & 4.1 & 9.5 & 2.4 & 35.3 & 4.3 & 2.9 \\
\hline Mullan Pass & 2.4 & 3.7 & 9.4 & 2.4 & 32.0 & 3.9 & 2.7 \\
\hline \multicolumn{8}{|c|}{ Wet Mountains site } \\
\hline Pueblo & 3.7 & 3.8 & 13.1 & 3.7 & 33.4 & 4.2 & 3.3 \\
\hline Alamosa & 3.2 & 3.3 & 11.2 & 3.2 & 28.7 & 3.7 & 2.8 \\
\hline
\end{tabular}

Table 9. Radionuclide contributors to the dose commitment to various organs for maximally exposed individual

\begin{tabular}{|c|c|c|c|c|c|c|c|}
\hline \multirow{2}{*}{ Radionuclide } & \multicolumn{7}{|c|}{ Contribution to dose commitment $(\%)$} \\
\hline & Total body & GI tract & Bone & Thyroid & Lungs & Kidneys & Liver \\
\hline \multicolumn{8}{|c|}{ Lehmi Pass site (Butte meteorology) } \\
\hline${ }^{232} \mathrm{Th}$ & 3 & $<1$ & 10 & 4 & $<1$ & 1 & 13 \\
\hline${ }^{228} \mathrm{Ra}$ & 36 & 2 & 23 & 36 & $<1$ & 4 & 6 \\
\hline${ }^{228} \mathrm{Ac}$ & $<1$ & $<1$ & $<1$ & $<1$ & $<1$ & $<1$ & $<1$ \\
\hline${ }^{228} \mathrm{Th}$ & 1 & $<1$ & 2 & 2 & $<1$ & $<1$ & 3 \\
\hline${ }^{24} \mathrm{Ra}$ & $<1$ & $<1$ & $<1$ & $<1$ & $<1$ & $<1$ & $<1$ \\
\hline${ }^{220} \mathrm{Rn}+\mathrm{D}^{a}$ & 59 & 98 & 65 & 58 & 98 & 95 & 78 \\
\hline
\end{tabular}

\begin{tabular}{lrrrrrrr} 
& \multicolumn{7}{c}{ Wet Mountains site (Pueblo meteorology) } \\
${ }^{232} \mathrm{Th}$ & 4 & $<1$ & 12 & 4 & $<1$ & 2 & 18 \\
${ }^{228} \mathrm{Ra}$ & 59 & 4 & 42 & 59 & $<1$ & 9 & 13 \\
${ }^{228} \mathrm{Ac}$ & $<1$ & $<1$ & $<1$ & $<1$ & $<1$ & $<1$ & $<1$ \\
${ }^{228} \mathrm{Th}$ & 2 & 1 & 3 & 2 & 2 & 1 & 5 \\
${ }^{224} \mathrm{Ra}$ & $<1$ & $<1$ & $<1$ & $<1$ & $<1$ & $<1$ & $<1$ \\
$220 \mathrm{Rn}+\mathrm{D}^{a}$ & 35 & 94 & 43 & 35 & 96 & 87 & 63
\end{tabular}

${ }^{a}$ Contribution of ${ }^{220} \mathrm{Rn}$ and daughters of ${ }^{220} \mathrm{Rn}$. 
23 when the distance to the maximally exposed individual is reduced by one-half Individual dose commitments calculated in this report could be reduced as necessary by imposing more stringent controls on the handling of ore and tallings and/or by more effective control of airborne particulates at the mill site

Maximum individual doses from thorium mining and milling appear to be similar in magnitude to those reported in assessments on uranium mining and milling operations ${ }^{16}$ However, it is emphasized that many of the assumptions made in this study are based on extrapolations from current practices in the uranium mining and milling industry, and this conclusion 1s, therefore, subject to uncertainty Consequently, as the thorium production industry expands to accommodate the demand for thorium as a fertile material in nonprolfferative fuel cycles, assessments such as this one should be extended to include on-site measurements of source terms and meteorological and environmental parameters

\subsection{Population doses}

The population residing within $80 \mathrm{~km}$ of the Lemhı Pass site is small $(\sim 15,000$ people) Consequently, population dose commitments in man-rems for the hypothetical thorrum mine and mill (Table 10) are relatively low The critical organs are bone, lungs, and kidneys, with the highest dose, 07 man-rem, received by the lungs The most important radionuclides (Table 11) include ${ }^{220} \mathrm{Rn}$ and its daughters, which deliver 64 to $98 \%$ of the dose to these organs Radium-228 is the second most important contributor, with the remainder of the dose due to ${ }^{232} \mathrm{Th}$ and ${ }^{228} \mathrm{Th}$ The dose to total body is divided between inhalation (39\%), surface exposure (36\%), and ingestion (25\%) Dose to bone is primarily by inhalation (53\%), while surface exposure and ingestion contribute 18 and $27 \%$ respectively Exposure to lungs is almost entirely from inhalation of particulate matter $(98 \%)$

In addition to the small number of individuals living near the site, one factor leading to relatively low population exposures from thorium mining and milling is the rapid decay of ${ }^{220} \mathrm{Rn}(55.6 \mathrm{sec})$ compared with that of ${ }^{22} \mathrm{Rn}$ ( 38 days) This property implies that the mean distance of ${ }^{22}{ }^{0} \mathrm{Rn}$ transport from the site will be relatively short before decay to particulate daughters occurs Since the probability of deposition through washout, rainout, or gravitational settling is greater for partıculates than gases, daughters of ${ }^{220} \mathrm{Rn}$ are less likely than those of ${ }^{22} \mathrm{Rn}$ to reach populated areas

Table 10. Population dose commitment to total body and various organs from radioactivity released to the atmosphere during one year of facility operation

\begin{tabular}{|c|c|c|c|c|c|c|c|}
\hline \multirow{2}{*}{ Meteorology } & \multicolumn{7}{|c|}{ Dose commitment (man-rems) } \\
\hline & Total body & GI tract & Bone & Thyroid & Lungs & Kıdneys & Liver \\
\hline \multicolumn{8}{|c|}{ Lemhi Pass site ${ }^{a}$} \\
\hline Butte & 005 & 003 & 01 & 005 & 07 & 007 & 006 \\
\hline Mullan Pass & 005 & 003 & 01 & 005 & 08 & 008 & 006 \\
\hline \multicolumn{8}{|c|}{ Wet Mountains site $b$} \\
\hline Pueblo & 03 & 01 & 07 & 02 & 28 & 03 & 03 \\
\hline Alamosa & 03 & 02 & 09 & 03 & 37 & 04 & 03 \\
\hline
\end{tabular}

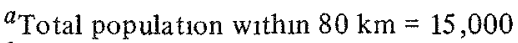

${ }^{b}$ Total population within $80 \mathrm{~km}=260,000$ 
Table 11. Radionuclide contributions to the population dose commitment to various organs

\begin{tabular}{|c|c|c|c|c|c|c|}
\hline \multirow{2}{*}{ Radionuclide } & \multicolumn{6}{|c|}{ Contribution to the dose commitment $(\%)$} \\
\hline & Total body & GI tract & Bone & Thyroid & Lungs & Kidneys \\
\hline \multicolumn{7}{|c|}{ Lemhi Pass site (Butte meteorology) } \\
\hline${ }^{232} \mathrm{Th}$ & 3 & $<1$ & 12 & 3 & $<1$ & 1 \\
\hline${ }^{228} \mathrm{Ra}$ & 28 & 7 & 22 & 28 & $<1$ & 4 \\
\hline${ }^{228} \mathrm{Ac}$ & $<1$ & $<1$ & $<1$ & $<1$ & $<1$ & $<1$ \\
\hline${ }^{228} \mathrm{Th}$ & 2 & 2 & 2 & 2 & $<1$ & $<1$ \\
\hline${ }^{224} \mathrm{Ra}$ & $<1$ & $<1$ & $<1$ & $<1$ & $<1$ & $<1$ \\
\hline $220 \mathrm{Rn}+\mathrm{D}^{a}$ & 67 & 91 & 64 & 67 & 98 & 94 \\
\hline \multicolumn{7}{|c|}{ Wet Mountains site (Alamosa meteorology) } \\
\hline${ }^{2}{ }^{32} \mathrm{Th}$ & 3 & $<1$ & 13 & 3 & $<1$ & 1 \\
\hline${ }^{228} \mathrm{Ra}$ & 48 & 16 & 40 & 48 & $<1$ & 10 \\
\hline${ }^{228} \mathrm{Ac}$ & $<1$ & $<1$ & $<1$ & $<1$ & $<1$ & $<1$ \\
\hline${ }^{228} \mathrm{Th}$ & 3 & 3 & 3 & 3 & 2 & 1 \\
\hline${ }^{22}{ }^{4} \mathrm{Ra}$ & $<1$ & $<1$ & $<1$ & $<1$ & $<1$ & $<1$ \\
\hline $2={ }^{0} \mathrm{Rn}+\mathrm{D}^{a}$ & 46 & 81 & 45 & 46 & 97 & 87 \\
\hline
\end{tabular}

${ }^{a}$ Contribution of ${ }^{220} \mathrm{Rn}$ and daughters of ${ }^{22}{ }^{\circ} \mathrm{Rn}$.

\section{REPROCESSING AND REFABRICATION OF $\left({ }^{232} \mathrm{Th},{ }^{233} \mathrm{U}\right)$ CARBIDE FUELS}

\subsection{Description of Reprocessing and Refabrication Plants}

Plants for the reprocessing and refabrication of irradiated nuclear fuels are designed and constructed to minimize exposure of operating personnel to radioactivity and to control the release of radioactivity to the environment. The principal control is provided by a primary cell which for recently irradiated and recycled thorium and thorium. ${ }^{23} \mathrm{U}$ fuels must have thick concrete walls for protection from gamma radiation. A tightly constructed building serves as the secondary container. Additional control over release of radioactivity is obtained by maintaining pressure differentials between the work cells, building interior, and the building exterior to assure that any atmospheric in-leakage will be from a clean area into the contaminated or potentially contaminated areas. The working volumes of cells and reaction vessels located in the cells are purged or vented to remove gaseous reaction products. These gaseous streams are treated before venting to the atmosphere to remove acids, various radioactive species, and entrained particles.

The operations used in aqueous reprocessing of spent thorium-uranium carbide fuels and the gaseous radioactive isotopes which will be present in the off-gas system are shown in Fig. 7. The methods of treating the off-gas to control the release of these isotopes is shown in Fig. 8. The principal steps in reprocessing are a mechanical shearing operation to expose the fuel for chemical treatment, an oxidation step to convert the carbide fuel to oxide, nitric acid dissolution, solvent extraction to separate thorium and uranium from fission and decay products, and a conversion step to yield thorium oxide and uranium oxide products. Off-gas treatment is designed to separate radioactive nuclides from the nonradioactive gases in the effluent and to convert some radioactive gases to a condensed form, such as liquid or solid. Tritium and ${ }^{14} \mathrm{C}$ may be converted to tritiated water and $\mathrm{CO}_{2}$; the latter is then reacted further to form a solid carbonate. Krypton- 85 remains a gas and is compressed for storage in metallic cylinders. The high-level liquid effluent from reprocessing is concentrated by evaporation. The reader is referred to earlier publications for additional information on the choice of flowsheets for reprocessing and effluent treatment. ${ }^{2,20,21}$ The 


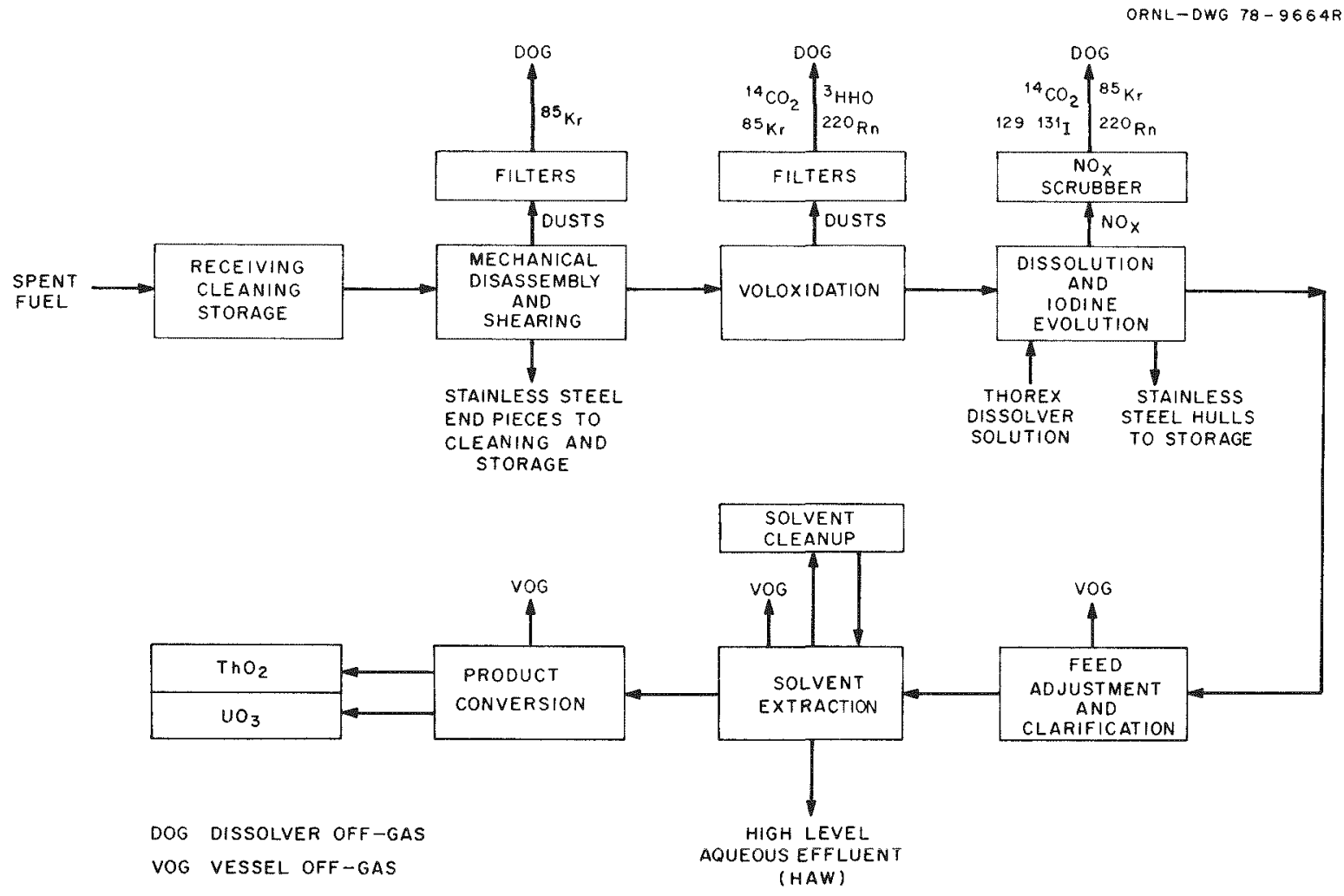

Fig. 7. Conceptual chemical flow diagram for reprocessing spent thorium-uranium carbide fuels.

ultimate disposal of these concentrated wastes is the subject of an ongoing DOE development program and is not considered here

The synthesis and refabrication of thorium-uranium carbide fuel pellets requires a serres of mechanical steps and high-temperature treatments As shown in Fig 9, thorlum oxide or a mixture of thorium oxide plus uranium oxide is mixed with carbon then heated at a high temperature to remove oxygen and form carbide phases (carbothermic reduction) The resulting carbides are ground to fine powders, pressed, and sintered to the required density. Since the carbide product will oxidize readily, especially in the fine powder state, a protective atmosphere of chemically inert gas, such as argon, must be provided An inert-gas purge is also used to remove the gaseous products of the reduction process Radioactivity is introduced into the off-gas in the form of small entraned particles and radon gas Entrainment of particles results from handling fuel powders at several steps in the preparation of the fuel In addition, the radiossotopes of lead $\left({ }^{212} \mathrm{~Pb}\right)$, bismuth $\left({ }^{212} \mathrm{~B}\right)$, and polonium $\left({ }^{212} \mathrm{Po}\right.$ and $\left.{ }^{216} \mathrm{Po}\right)$, formed from decay of thorium $\left({ }^{228} \mathrm{Th}\right)$, are expected to be released from the fuel during heating at the high temperatures required for carbide synthesis and sintering of pellets It is assumed that no contaminated process-liquid waste is released directly to the environment, but some liquid, potentrally contammated at very low levels, may be released as a result of collection from laboratory sinks, mopping of floors, laundry water, and showers The radioactive content cannot exceed and must not routinely equal the limits set by Title 10, Code of Federal Regulations, Part 20 (10CFR Part 20) (Table II, Column 2, Append1x B) Experience reported by the Nuclear Regulatory Commission $^{22}$ in fabricating (U,Pu)O fuel suggests that an annual average concentration equal to $7 \%$ of the $10 \mathrm{CFR} 201 \mathrm{~lm}$ ts may be expected in potentrally contaminated liquid from a refabrication plant 
1 DISSOLVER OFF-GASES (DOG)

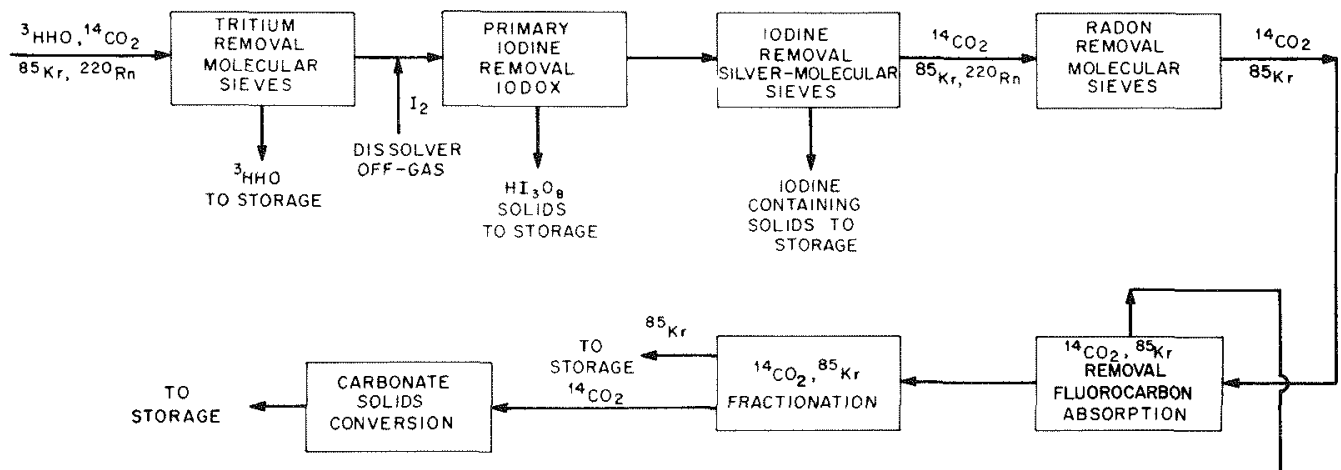

2 VESSEL OFF-GASES (VOG)

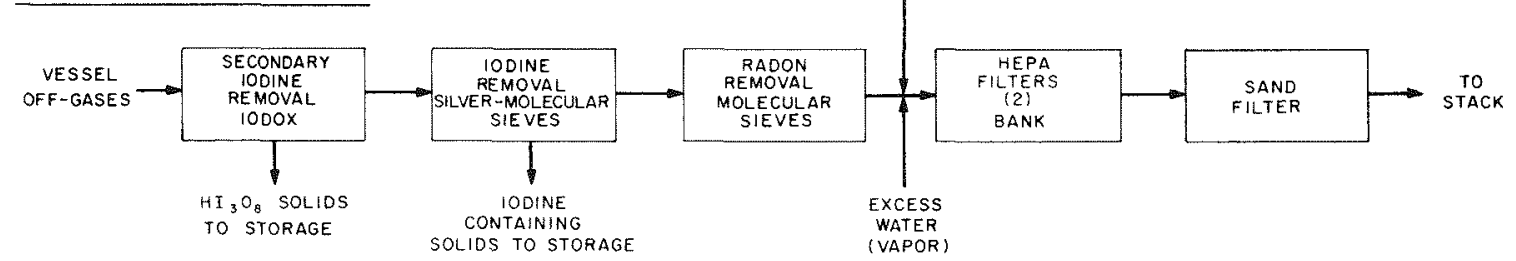

3 LLIQUIDS

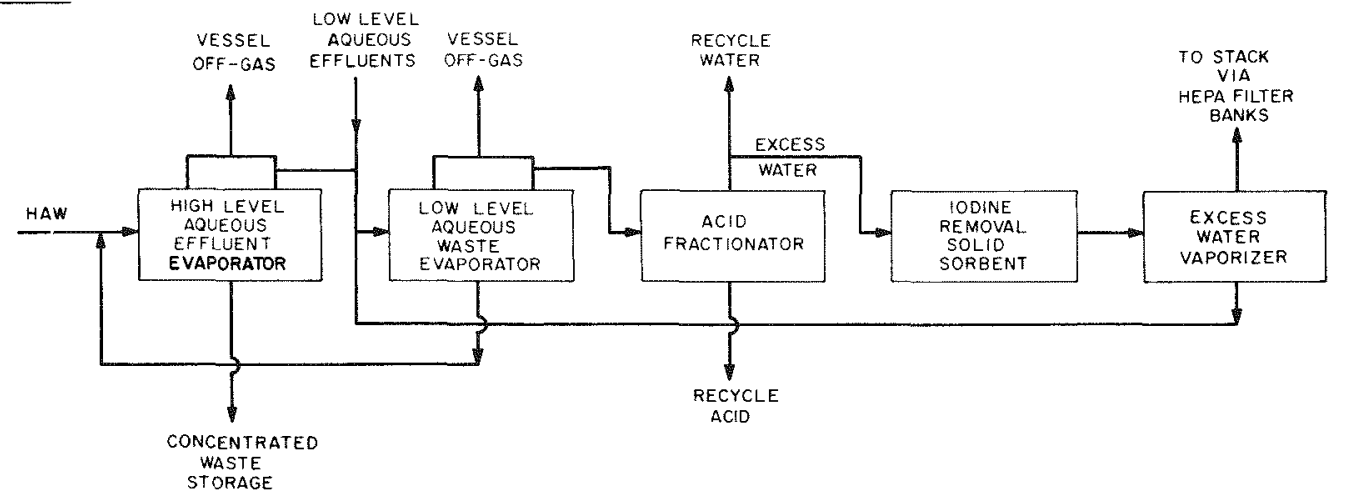

Fig. 8. Radioactive effluents control system.

\subsection{Source Terms from Reprocessing and Refabrication}

\subsubsection{Reprocessing}

The composition of the $(\mathrm{Th}, \mathrm{U}) \mathrm{C}$ reactor fuel at discharge from the reactor and after being held in storage for one year was calculated by the ORIGEN computer code, appropriate confinement factors for reprocessing ${ }^{4}$ were applied, and the annual release calculated for a reprocessing plant in which the fuel required to generate $50 \mathrm{GW}(\mathrm{e})$-years of energy was treated. These results are given in Table 12, along with the source terms, for comparison of radioactivity released during reprocessing of (Th, U)C fuel with that from $(\mathrm{U}, \mathrm{Pu}) \mathrm{C}$ fuel calculated in an earlier study. ${ }^{23}$ 
ORNL-DWG 7812803

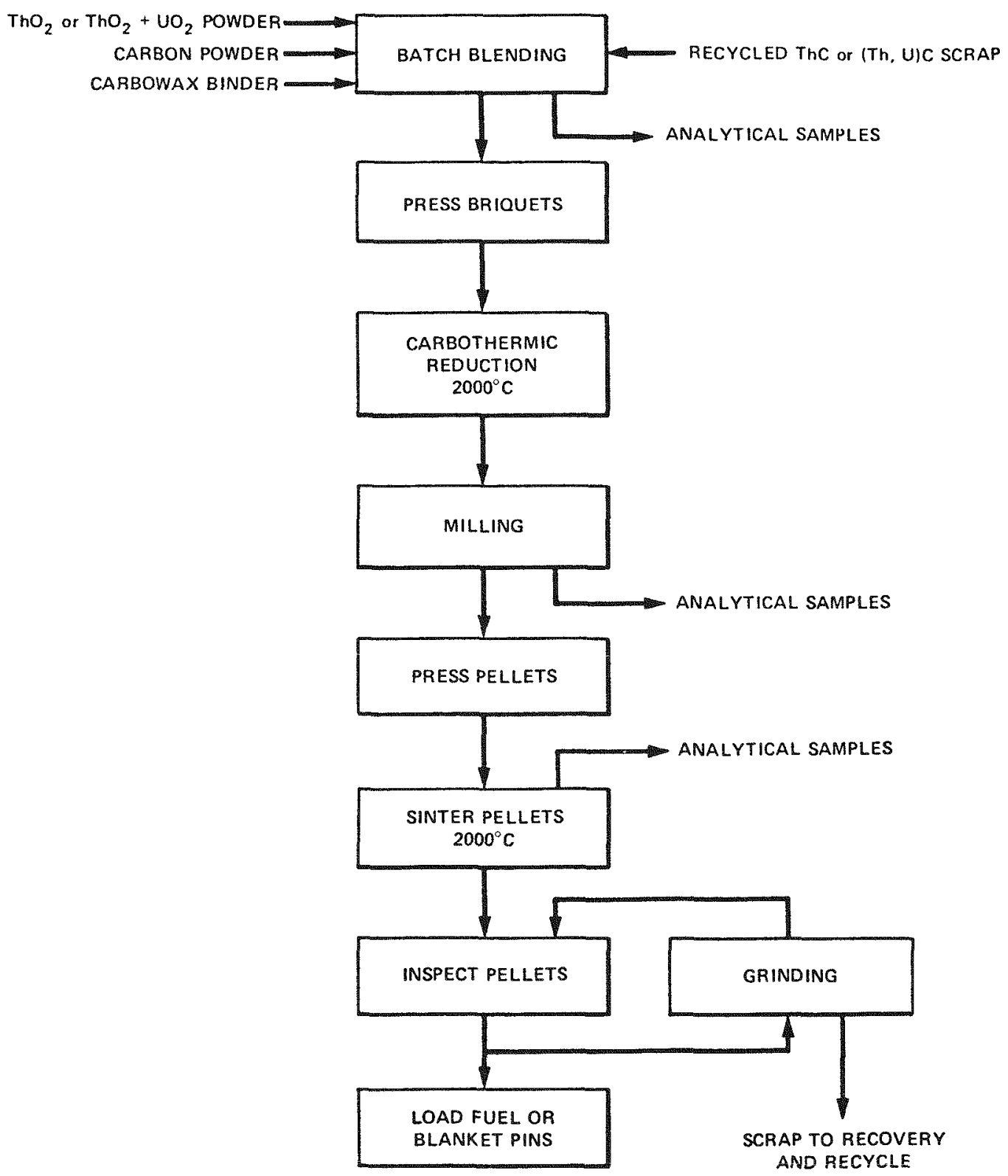

Fig. 9. Flowchart for synthesis of $\mathrm{ThC}_{0.95}$ and $(\mathrm{Th}, \mathrm{U}) \mathrm{C}_{0.95}$ and refabrication of pellets.

\subsubsection{Refabrication}

Confinement factors for gaseous and particulate radioactivity entrained in the process and cell off-gas systems during refabrication of $(\mathrm{Th}, \mathrm{U}) \mathrm{C}$ fuel and the resulting amount of airborne activity released from the refabrication plant are given in Table 13, along with releases for $(\mathrm{U}, \mathrm{Pu}) \mathrm{C}$ fuel. ${ }^{23}$ The radioactivity which may be contained in potentially contaminated liquid released from the refabrication plant is presented in 
Table 12. Comparison of calculated gas-borne effluents from a chemical plant reprocessing one-year-decayed

$(\mathrm{Th}, \mathrm{U}) \mathrm{C}$ and (U,Pu)C FBR fuels equivalent to $50 \mathrm{GW}(\mathrm{e})$-years of energy generated

\begin{tabular}{|c|c|c|}
\hline \multirow{2}{*}{ Nuclide } & \multicolumn{2}{|c|}{ Radioactivity releases $(\mathrm{Bq} / \text { year })^{a}$} \\
\hline & $(\mathrm{Th}, \mathrm{U}) \mathrm{C}$ & $(\mathrm{U}, \mathrm{Pu}) \mathrm{C}$ \\
\hline \multicolumn{3}{|c|}{ Volatiles } \\
\hline${ }^{3} \mathrm{H}$ & $3.1 \mathrm{E} 15^{b}$ & $3.4 \mathrm{E} 15$ \\
\hline${ }^{14} \mathrm{C}$ & $1.4 \mathrm{E} 12$ & $7.5 \mathrm{E} 11$ \\
\hline${ }^{85} \mathrm{Kr}$ & $1.2 \mathrm{E} 16$ & $2.8 \mathrm{E} 15$ \\
\hline $129 \mathrm{I}$ & $3.0 \mathrm{E} 8$ & $2.1 \mathrm{E} 8$ \\
\hline${ }^{131} \mathrm{I}$ & $2.4 \mathrm{E} 2$ & $1.7 \mathrm{E} 2$ \\
\hline${ }^{20} \mathrm{Rn}$ & $9.7 \mathrm{E} 13$ & $c$ \\
\hline \multicolumn{3}{|c|}{ Semivolatiles } \\
\hline${ }^{103} \mathrm{Ru}$ & $c$ & $2.5 \mathrm{E} 8$ \\
\hline${ }^{106} \mathrm{Ru}$ & $2.9 \mathrm{E} 9$ & $2.9 \mathrm{E} 10$ \\
\hline \multicolumn{3}{|c|}{ Particulates } \\
\hline${ }^{54} \mathrm{Mn}$ & $1.0 \mathrm{E} 4$ & $c$ \\
\hline${ }^{55} \mathrm{Fe}$ & $2.2 \mathrm{E} 7$ & $c$ \\
\hline${ }^{58} \mathrm{Co}$ & $1.1 \mathrm{E} 6$ & $c$ \\
\hline${ }^{89} \mathrm{Sr}$ & $2.9 \mathrm{E} 8$ & $6.6 \mathrm{E} 7$ \\
\hline${ }^{90} \mathrm{Sr}$ & $1.4 \mathrm{E} 9$ & $4.1 \mathrm{E} 8$ \\
\hline${ }^{90} \mathrm{Y}$ & $1.4 \mathrm{E} 9$ & $4.1 \mathrm{E} 8$ \\
\hline${ }^{91} \mathrm{Y}$ & $5.3 \mathrm{E} 8$ & $1.6 \mathrm{E} 8$ \\
\hline${ }^{95} \mathrm{Zr}$ & $8.0 \mathrm{E} 8$ & $4.5 \mathrm{E} 8$ \\
\hline${ }^{95} \mathrm{Nb}$ & $1.7 \mathrm{E} 9$ & $9.5 \mathrm{E} 8$ \\
\hline${ }^{99} \mathrm{Tc}$ & $1.4 \mathrm{E} 5$ & $c$ \\
\hline${ }^{110} \mathrm{Ag}$ & $c$ & $8.2 \mathrm{E} 7$ \\
\hline${ }^{125} \mathrm{Sb}$ & $1.8 \mathrm{E} 8$ & $1.2 \mathrm{E} 8$ \\
\hline $125 \mathrm{Te}$ & $4.5 \mathrm{E} 7$ & $c$ \\
\hline $127 \mathrm{Te}$ & $6.7 \mathrm{E} 7$ & $2.8 \mathrm{E} 7$ \\
\hline${ }^{134} \mathrm{Cs}$ & $1.7 \mathrm{E} 8$ & $2.0 \mathrm{E} 8$ \\
\hline${ }^{137} \mathrm{Cs}$ & $1.3 \mathrm{E} 9$ & $1.1 \mathrm{E} 9$ \\
\hline${ }^{144} \mathrm{Ce}$ & $8.6 \mathrm{E} 9$ & $5.5 \mathrm{E} 9$ \\
\hline${ }^{147} \mathrm{Pm}$ & $2.6 \mathrm{E} 9$ & $2.5 \mathrm{E} 9$ \\
\hline $151 \mathrm{Sm}$ & $c$ & $3.9 \mathrm{E} 7$ \\
\hline${ }^{154} \mathrm{Eu}$ & $c$ & $1.7 \mathrm{E} 7$ \\
\hline $155 \mathrm{Eu}$ & $c$ & $1.3 \mathrm{E} 8$ \\
\hline $212 \mathrm{~Pb}$ & $1.9 \mathrm{E} 7$ & $c$ \\
\hline${ }^{212} \mathrm{Bi}$ & $1.9 \mathrm{E} 7$ & $c$ \\
\hline${ }^{224} \mathrm{Ra}$ & $1.9 \mathrm{E} 7$ & $c$ \\
\hline${ }^{228} \mathrm{Ra}$ & $3.6 \mathrm{E} 2$ & $c$ \\
\hline${ }^{227} \mathrm{Ac}$ & $8.4 \mathrm{E} 3$ & $c$ \\
\hline${ }^{231} \mathrm{~Pa}$ & $1.4 \mathrm{E} 6$ & $c$ \\
\hline${ }^{241} \mathrm{Am}$ & $c$ & $5.1 \mathrm{E} 6$ \\
\hline${ }^{243} \mathrm{Am}$ & $c$ & $5.2 \mathrm{E} 4$ \\
\hline${ }^{242} \mathrm{Cm}$ & $c$ & $2.5 \mathrm{E} 7$ \\
\hline${ }^{243} \mathrm{Cm}$ & $c$ & $5.9 \mathrm{E} 4$ \\
\hline${ }^{244} \mathrm{Cm}$ & $c$ & $7.4 \mathrm{E} 5$ \\
\hline \multicolumn{3}{|c|}{ Thorium } \\
\hline${ }^{228} \mathrm{Th}$ & $1.9 \mathrm{E} 8$ & $c$ \\
\hline $229 \mathrm{Th}$ & $1.9 \mathrm{E} 4$ & $c$ \\
\hline${ }^{230} \mathrm{Th}$ & $4.9 \mathrm{E} 3$ & $c$ \\
\hline $232 \mathrm{Th}$ & $1.5 \mathrm{E} 4$ & $c$ \\
\hline
\end{tabular}


Table 12 (contmued)

\begin{tabular}{|c|c|c|}
\hline \multirow{2}{*}{ Nuclide } & \multicolumn{2}{|c|}{ Radioactivity releases $(\mathrm{Bq} / \text { year })^{a}$} \\
\hline & $(\mathrm{Th} \mathrm{U}) \mathrm{C}$ & $(\mathrm{U}, \mathrm{Pu}) \mathrm{C}$ \\
\hline \multicolumn{3}{|c|}{ Uranium } \\
\hline $232 \mathrm{U}$ & 3 1E8 & $c$ \\
\hline $233 \mathrm{U}$ & $82 \mathrm{E} 7$ & $c$ \\
\hline $234 \mathrm{U}$ & $14 \mathrm{E} 7$ & $62 \mathrm{E} 3$ \\
\hline $235 \mathrm{U}$ & $c$ & $30 \mathrm{E} 2$ \\
\hline $236 \mathrm{U}$ & $c$ & $78 \mathrm{E} 2$ \\
\hline${ }^{238} \mathrm{U}$ & $c$ & $31 \mathrm{E} 4$ \\
\hline \multicolumn{3}{|c|}{ Neptunrum } \\
\hline${ }^{235} \mathrm{~Np}$ & $24 \mathrm{E} 2$ & $c$ \\
\hline $237 \mathrm{~Np}$ & $50 \mathrm{E} 3$ & $c$ \\
\hline \multicolumn{3}{|c|}{ Plutonum } \\
\hline $237 \mathrm{Pu}$ & $17 \mathrm{E} 1$ & $11 \mathrm{E} 4$ \\
\hline${ }^{238} \mathrm{Pu}$ & $17 \mathrm{E} 6$ & $20 \mathrm{E} 8$ \\
\hline${ }^{239} \mathrm{Pu}$ & $80 \mathrm{E} 1$ & $99 \mathrm{E} 7$ \\
\hline${ }^{240} \mathrm{Pu}$ & $64 \mathrm{E} 0$ & $89 \mathrm{E} 7$ \\
\hline${ }^{241} \mathrm{Pu}$ & $c$ & $33 \mathrm{E} 9$ \\
\hline${ }^{242} \mathrm{Pu}$ & $c$ & $43 \mathrm{E} 4$ \\
\hline $\begin{array}{r}\quad \begin{array}{r}a_{1 \mathrm{~B}} \\
b_{31} \\
c_{\mathrm{Nuc}}\end{array} \\
\text { than } 00 \\
\text { fuel }\end{array}$ & $\begin{array}{l}\text { year } \\
\text { concentratic } \\
\text { atial inhalati }\end{array}$ & $\begin{array}{l}\text { bute less } \\
\text { the spent }\end{array}$ \\
\hline
\end{tabular}

Table 14 In comparing the potential release of isotopes of uranium and thorium contained in the liquid effluent from the refabrication plant, the reader should be aware that feed for preparation of the thorium based fuel 1 is received as oxide, however, the uranium-based fuel is prepared from $\mathrm{UF}_{6}$, therefore the fabrication process contains a step to convert $\mathrm{UF}_{6}$ to $\mathrm{UO}_{2}$ by the ammonium diuranate process with an attendant release of $0004 \mathrm{~m}^{3} / \mathrm{sec}(86,500 \mathrm{gpd})$ of water potentially contaminated at a very low level ${ }^{23}$ This liquid effluent is assumed to be released to a river having a minimum flow rate of $17 \mathrm{~m}^{3} / \mathrm{sec}(600 \mathrm{cfs})$ Also, a smaller confinement factor is provided for the fabrication of blanket fuel containing depleted uranium than for recycled thorium because of the lower radıotoxıcity of the former

\section{Radiological Impact}

The meteorological summaries input to the AIRDOS-II code were the same as those used in the environmental statement for the Liquid-Metal Fast Breeder Reactor (LMFBR) Program ${ }^{24}$ Weather data were obtained from 18 stations in the continental United States The data were averaged to obtain joint wind speed and stability categories for the 16 principal compass directions, bounded by radial distances ranging from 10 to $80 \mathrm{~km}$ Population distribution was also taken fiom the LMFBR environmental statement 
Table 13. Radionuclides released as gas-borne effluents from refabricating $(\mathrm{Th}, \mathrm{U}) \mathrm{C}$ and $(\mathrm{U}, \mathrm{Pu}) \mathrm{C}$ FBR fuels used to generate $50 \mathrm{GW}(\mathrm{e})$-years of energy ${ }^{a}$

\begin{tabular}{|c|c|c|c|}
\hline \multirow{2}{*}{ Radionuclide } & \multirow{2}{*}{$\begin{array}{c}\text { Refabrication plant } \\
\text { confinement factor } \\
\text { (CF) }\end{array}$} & \multicolumn{2}{|c|}{ Radioactivity released $(\mathrm{Bq} / \text { year })^{b}$} \\
\hline & & $(\mathrm{Th}, \mathrm{U}) \mathrm{C}$ & $(\mathrm{U}, \mathrm{Pu}) \mathrm{C}$ \\
\hline${ }^{212} \mathrm{~Pb}$ & $1 \mathrm{E} 11^{c, d}$ & $1.1 \mathrm{E} 6$ & \\
\hline${ }^{212} \mathrm{Bi}$ & $1 \mathrm{E} 11$ & $1.1 \mathrm{E} 6$ & \\
\hline $\begin{array}{l}212 \mathrm{Po} \\
216 \mathrm{PO}\end{array}$ & $1 \mathrm{E} 11$ & $\begin{array}{l}7.3 \mathrm{E} 5 \\
1.1 \mathrm{E} 6\end{array}$ & \\
\hline${ }^{220} \mathrm{Rn}$ & $2 \mathrm{E} 3^{e}$ & $1.1 \mathrm{E} 14$ & \\
\hline $224 \mathrm{Ra}$ & $1 \mathrm{E} 12$ & $1.1 \mathrm{E} 5$ & \\
\hline $228 \mathrm{Ra}$ & $1 \mathrm{E} 12$ & $7.1 \mathrm{E}-1$ & \\
\hline${ }^{225} \mathrm{Ac}$ & $1 \mathrm{E} 12$ & $9.5 \mathrm{E} 0$ & \\
\hline${ }^{228} \mathrm{Th}$ & $1 \mathrm{E} 12$ & $1.1 \mathrm{E} 5$ & $2.7 \mathrm{E}-1$ \\
\hline $229 \mathrm{Th}$ & $1 \mathrm{E} 12$ & $9.5 \mathrm{E} 0$ & \\
\hline${ }^{230} \mathrm{Th}$ & $1 \mathrm{E} 12$ & $2.4 \mathrm{E} 0$ & \\
\hline${ }^{231} \mathrm{Th}$ & $2.6 \mathrm{E} 5^{f}$ & & $4.8 \mathrm{E} 5$ \\
\hline $232 \mathrm{Th}$ & $1 \mathrm{E} 12$ & $7.3 \mathrm{E} 0$ & \\
\hline${ }^{234} \mathrm{Th}$ & $2.6 \mathrm{E} 5^{f}$ & & $3.5 \mathrm{E} 7$ \\
\hline${ }^{232} \mathrm{U}$ & $1 \mathrm{E} 12$ & $1.5 \mathrm{E} 5$ & \\
\hline${ }^{233} \mathrm{U}$ & $1 \mathrm{E} 12$ & $4.1 \mathrm{E} 4$ & \\
\hline${ }^{234} \mathrm{U}$ & $1 \mathrm{E} 12,2.6 \mathrm{E} 5$ & $7.3 \mathrm{E} 3$ & $3.8 \mathrm{E} 6$ \\
\hline${ }^{235} \mathrm{U}$ & $2.6 \mathrm{E} 5^{f}$ & & $4.8 \mathrm{E} 5$ \\
\hline${ }^{236} \mathrm{U}$ & $2.6 \mathrm{E} 5^{f}$ & & $6.0 \mathrm{E} 5$ \\
\hline${ }^{238} \mathrm{U}$ & $2.6 \mathrm{E} 5^{f}$ & & $3.5 \mathrm{E} 7$ \\
\hline${ }^{236} \mathrm{Pu}$ & $1 \mathrm{E} 12$ & & $1.4 \mathrm{E} 2$ \\
\hline${ }^{238} \mathrm{Pu}$ & $1 \mathrm{E} 12$ & & $3.2 \mathrm{E} 5$ \\
\hline${ }^{239} \mathrm{Pu}$ & $1 \mathrm{E} 12$ & & $1.6 \mathrm{E} 5$ \\
\hline${ }^{240} \mathrm{Pu}$ & $1 \mathrm{E} 12$ & & $1.4 \mathrm{E} 5$ \\
\hline${ }^{241} \mathrm{Pu}$ & $1 \mathrm{E} 12$ & & $5.1 \mathrm{E} 6$ \\
\hline${ }^{242} \mathrm{Pu}$ & 1E12 & & $6.0 \mathrm{E} 1$ \\
\hline
\end{tabular}

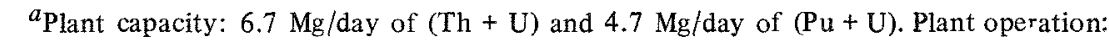
300 days per year. Effluent volume: $95 \mathrm{~m}^{3} / \mathrm{sec}\left(2 \times 10^{5} \mathrm{scfm}\right)$ from $18-\mathrm{m}$-high $(60-\mathrm{ft})$ rooftop stack [as assumed in U.S. AEC, Environmental Statement, Liquid-Metal Fast Breeder Reactor Program, WASH-1535, vols. I-VII (December 1974)].

$b_{1} \mathrm{~Bq} /$ year $=27 \mathrm{pCi} /$ year.

${ }^{c_{L}}$ Lower plant confinement factor results from volatility of $\mathrm{Pb}, \mathrm{Bi}$, and $\mathrm{Po}$ during heat treatments.

$d_{1 \mathrm{E} 11}=1 \times 10^{11}$.

${ }^{e}$ Confinement factor assumed for approximately 10-min holdup of $\mathrm{Rn}$ in molecularsieve bed.

$f_{\text {Lower }}$ confinement factor applied for depleted uranium than for recycled thorium feed used in fabrication of blanket fuel because of the lower radiotoxicity of the former.

\subsubsection{Maximum individual doses}

The maximum individual doses were calculated assuming a plant boundary located $1 \mathrm{~km}$ from the reprocessing and refabrication plants. Dose commitments from the reprocessing plant and a listing of the principal contributors are given in Tables 15 and 16. The thyroid receives the highest dose ( 6.8 millirems); however, allowable exposure for this organ is generally recognized to be higher than those for the total body and other organs. ${ }^{25}$ Tritium contributes more than $60 \%$ of the dose to total body, lungs, and kidneys. Cesium-137 and ${ }^{14} \mathrm{C}$ are also significant contributors; ${ }^{232} \mathrm{U}$ makes an appreciable contribution to the total body and all organs. 
Table 14. Radionuclides in potentially contaminated liquid effiuent from refabricating (Th, U)C and (U,Pu)C FBR fuels used to generate $50 \mathrm{GW}(\mathrm{e})$-years of energy ${ }^{a}$

\begin{tabular}{|c|c|c|c|}
\hline \multirow{2}{*}{ Radionuclide } & \multirow{2}{*}{$\begin{array}{c}\text { Radioactivity } \\
\text { concentration guide, } \\
\text { water }^{c}(\mathrm{~Bq} / \mathrm{ml})\end{array}$} & \multicolumn{2}{|c|}{$\begin{array}{l}\text { Potentidl activity released } \\
(\mathrm{Bq} / \mathrm{y} \text { ear })^{b}\end{array}$} \\
\hline & & $(\mathrm{Th}, \mathrm{U}) \mathrm{C}^{d}$ & $(\mathrm{U}, \mathrm{Pu}) \mathrm{C}^{d}$ \\
\hline${ }^{208} \mathrm{~T} 1$ & $19 \mathrm{E} 2^{e}$ & $94 \mathrm{E} 3$ & \\
\hline${ }^{212} \mathrm{~Pb}$ & $74 \mathrm{E}-1$ & $26 \mathrm{~F} 4$ & \\
\hline${ }^{212} \mathrm{~B}_{1}$ & $15 \mathrm{E} 1$ & $26 \mathrm{E} 4$ & \\
\hline${ }^{212} \mathrm{Po}$ & $37 \mathrm{E} 4$ & $17 \mathrm{E} 4$ & \\
\hline${ }^{216} \mathrm{Po}$ & $37 \mathrm{E} 4$ & $26 \mathrm{E} 4$ & \\
\hline $220 \mathrm{Rn}$ & $37 \mathrm{E} 4$ & $26 \mathrm{E} 4$ & \\
\hline${ }^{224} \mathrm{Ra}$ & $74 \mathrm{~L} 2$ & $26 \mathrm{E} 4$ & \\
\hline $225 \mathrm{Ra}$ & $19 \mathrm{E}-2$ & $30 \mathrm{E} 0$ & \\
\hline${ }^{228} \mathrm{Rd}$ & $11 \mathrm{E}-3$ & $16 \mathrm{E}-1$ & \\
\hline${ }^{225} \mathrm{AC}$ & $19 F-1$ & $30 \mathrm{E} 0$ & \\
\hline${ }^{228} \mathrm{Th}$ & $26 \mathrm{~F}-1$ & $26 \mathrm{E} 4$ & \\
\hline${ }^{229} \mathrm{Th}$ & $15 \mathrm{~L}-2$ & $30 \mathrm{E} 0$ & \\
\hline${ }^{230} \mathrm{Th}$ & $74 \mathrm{E}-2$ & $57 \mathrm{E}-1$ & \\
\hline $231 \mathrm{Th}$ & $75 \mathrm{E} 0$ & $96 \mathrm{E}-2$ & $12 \mathrm{E} 8 f$ \\
\hline $232 \mathrm{Th}$ & $74 \mathrm{E}-2$ & $17 \mathrm{E} 0$ & \\
\hline $234 \mathrm{Th}$ & $74 \mathrm{E}-1$ & & $93 \mathrm{E} 9 f$ \\
\hline $232 \mathrm{U}$ & $11 \mathrm{EO}$ & $35 \mathrm{E} 4$ & \\
\hline${ }^{23}{ }^{3} \mathrm{U}$ & $11 \mathrm{E} 0$ & $93 \mathrm{E} 3$ & \\
\hline${ }^{434} \mathrm{U}$ & $11 \mathrm{E} 0$ & $16 \mathrm{E} 3$ & $10 \mathrm{E} g f$ \\
\hline${ }^{235} \mathbf{U}$ & $11 \mathrm{E} 0$ & $96 \mathrm{E}-2$ & $12 \mathrm{E} 8^{f}$ \\
\hline $236 \mathrm{U}$ & $11 \mathrm{E} 0$ & $72 \mathrm{E}-1$ & $16 \mathrm{E} 8 f$ \\
\hline${ }^{238} \mathrm{U}$ & $15 \mathrm{E} 0$ & & $93 \mathrm{E} 9 f$ \\
\hline${ }^{236} \mathbf{P u}$ & $11 \mathrm{EO}$ & & $26 \mathrm{E} 3$ \\
\hline $238 \mathrm{Pu}$ & $19 \mathrm{E}-1$ & & $63 \mathrm{E} 6$ \\
\hline${ }^{2}{ }^{9}{ }^{9} \mathrm{Pu}$ & $19 \mathrm{E}-1$ & & $31 \mathrm{E} 6$ \\
\hline${ }^{240} \mathrm{Pu}$ & $19 \mathrm{E}-1$ & & $28 \mathrm{E} 6$ \\
\hline${ }^{241} \mathrm{Pu}$ & $74 \mathrm{E} 0$ & & $10 \mathrm{E} 8$ \\
\hline${ }^{242} \mathrm{Pu}$ & $19 \mathrm{E}-1$ & & $12 \mathrm{E} 3$ \\
\hline
\end{tabular}

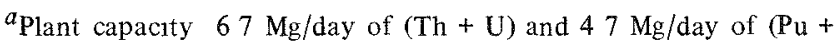
U) Plant operation 300 days per year Effluent volume $0012 \mathrm{~m}^{3} / \mathrm{sec}$ $\left(275 \times 10^{5} \mathrm{~g} / \mathrm{d}\right)$ total after in-plant dilution

$b_{1 \mathrm{~Bq}} /$ year $=27 \mathrm{pC} /$ year

${ }^{c}$ Radioactivity concentration guide in unrestricted areas, Title 10, Code of Federal Regulations, Part 20, revised January 1, 1976

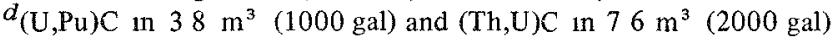
volume based on scaling of the assumptions in US Atomic Energy Commission, Environmental Statement, Liquid Metal Fast Breeder Reactor Program, WASH-1535, vols I-VII (December 1974) Results for $(\mathrm{U}, \mathrm{Pu}) \mathrm{C}$ fuel reported in $\mathrm{V} \mathrm{J}$ Tennery et al, Environmental Assess ment of LMFBR Advanced Fuels A Radiological Analysis of Fuel Reprocessing, Refabrication, and Transportation, ORNL-5230 (November 1976) Total radioactivity in liquid assumed equal to $7 \%$ of 10 CFR Part 20 limit Seven percent of CFR limit based on industrial small plant experience reported in Nuclear Regulatory Commission, Final Genertc Environmental Statement on Use of Recycle Plutonium in Mixed Oxide Fuel in Light Water Cooled Reactors, NUREG-0002, Chap IV, Sect D, p IV D-29 (August 1976)

$e_{1}$ E $2=19 \times 10^{2}$

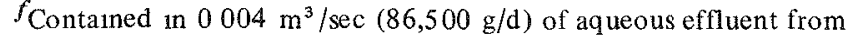
ammonium diuranate conversion process (based on USAEC and $\mathrm{V} J$ Tennery references in footnote $d$ ) 
Table 15. Maximum individual dose commitment (millirems) to total body and various organs due to radionuclide releases to the atmosphere during one year of reprocessing plant operation

\begin{tabular}{cccccc}
\hline Total body & GI tract & Bone & Thyroid & Lungs & Kidneys \\
\hline 3.1 & 4.6 & 4.1 & 6.8 & 3.3 & 2.9 \\
\hline
\end{tabular}

Table 16. Significant contributors to maximum individual dose commitment due to radionuclide releases to the atmosphere during reprocessing plant operation

\begin{tabular}{|c|c|c|c|c|c|c|}
\hline \multirow{2}{*}{ Radionuclide } & \multicolumn{6}{|c|}{ Contribution (\%) } \\
\hline & Total body & GI tract & Bone & Thyroid & Lungs & Kidneys \\
\hline${ }^{3} \mathrm{H}$ & 64 & 43 & 49 & 29 & 61 & 69 \\
\hline${ }^{14} \mathrm{C}$ & 8 & 4 & 11 & 2 & 3 & 5 \\
\hline${ }^{85} \mathrm{Kr}$ & 1 & $<1$ & 1 & $<1$ & 2 & 1 \\
\hline${ }^{90} \mathrm{Sr}$ & 1 & 1 & 9 & $<1$ & $<1$ & $<1$ \\
\hline${ }^{106} \mathrm{Ru}$ & 1 & 32 & 1 & 1 & 1 & 2 \\
\hline $129 I$ & $<1$ & $<1$ & $<1$ & 57 & $<1$ & $<1$ \\
\hline $137 \mathrm{Cs}$ & 13 & 6 & 12 & 6 & 10 & 13 \\
\hline${ }^{144} \mathrm{Ce}$ & $<1$ & 6 & $<1$ & $<1$ & 1 & $<1$ \\
\hline $2^{22} \mathrm{Rn}+$ daughters & $<1$ & $<1$ & 1 & $<1$ & 5 & 1 \\
\hline${ }^{228} \mathrm{Th}$ & 1 & $<1$ & 3 & $<1$ & 3 & $<1$ \\
\hline $232 \mathrm{U}$ & 9 & 5 & 12 & 4 & 12 & 7 \\
\hline${ }^{23}{ }^{3} \mathrm{U}$ & $<1$ & $<1$ & $<1$ & $<1$ & 1 & $<1$ \\
\hline
\end{tabular}

Maximum individual doses due to refabrication, and the major contributors to dose, are given in Tables 17 and 18. Doses are generally reduced with respect to those for reprocessing, with the exception of lung doses. Virtually all of the dose resulting from refabrication of fuel derives from ${ }^{22}{ }^{0} \mathrm{Rn}$ and its daughters; ${ }^{232} \mathrm{U}$ as such contributes about $1 \%$ of the total. Radon- 220 daughters, primarily ${ }^{212} \mathrm{~Pb}$, contribute essentially all of the dose to GI tract, bone, lungs, and kidneys and $99 \%$ of the dose to total body and thyroid. Holdup of ${ }^{220} \mathrm{Rn}$ for additional time prior to release from the refabrication plant, followed by HEPA

Table 17. Maximum individual dose commitment (man-rems) to total body and various organs due to radionuclide releases to the atmosphere during one year of refabrication plant operation

\begin{tabular}{cccccc}
\hline Total body & GI tract & Bone & Thyroid & Lungs & Kidneys \\
\hline 0.15 & 0.41 & 0.63 & 0.15 & 3.8 & 0.42 \\
\hline
\end{tabular}

Table 18. Significant contributors to maximum individual dose commitment due to radionuclide releases to the atmosphere during refabrication plant operation

\begin{tabular}{lrrrrrrr}
\hline \multirow{2}{*}{ Radionuclide } & \multicolumn{5}{c}{ Contribution (\%) } \\
\cline { 2 - 7 } & Total body & GI tract & Bone & Thyroid & Lungs & Kidneys \\
\hline${ }^{220} \mathrm{Rn}+$ daughters & 99 & $\sim 100$ & $\sim 100$ & 99 & $\sim 100$ & $\sim 100$ \\
$2{ }^{32} \mathrm{U}$ & 1 & $<1$ & $<1$ & 1 & $<1$ & $<1$ \\
\hline
\end{tabular}


filtration of daughter ${ }^{212} \mathrm{~Pb}$ particulates, and/or an increase in the effective stack height for the refabrication facility, would greatly decrease the dose to the lung for this plant Either procedure is technologically feasible if later found to be cost effective

The annual total-body, bone, and kıdney doses to individuals via aquatic pathways are summarized in Table 19 Dose commitments are dominated by ${ }^{228} \mathrm{Th}$, which contributes $80 \%$ of the dose to total body and about $90 \%$ of the dose to bone and kidney Liquid releases containing the radioactivity levels assumed in this work will cause very low total doses to individuals residing near a fuel refabrication facility

\subsection{Population doses}

Population exposures are calculated assuming approximately 1 millon people live within an $80-\mathrm{km}$ radius from the reprocessing and refabrication plants Thyroid receives the largest dose due to operation of the reprocessing plant (see Table 20) Relative doses to the total body, GI tract, bone, lungs, and kidneys parallel those for the maximally exposed individual Significant radionuclide contributors to the population dose are listed in Table 21 These results indicate that tritium is the most important contributor to all organs Ruthenum-106 and ${ }^{129} \mathrm{I}$ are seen to act as primary contributors to GI tract and thyrold respectively, while causing little dose to other organs Table 22 presents dose commitments to the population within $80 \mathrm{~km}$ of the refabrication plant and indicates that lungs receive the highest dose The major contributors are ${ }^{20} \mathrm{Rn}$ and its daughters (see Table 18) These results are smilar to those observed for the maximally exposed individual located adjacent to the refabrication facility boundary

Table 19. Summary of dose commitments to undividuals due to one year of release of hquid effluents from a $(\mathrm{Th}, \mathrm{U}) \mathrm{C}$ fuels refabrication plant

\begin{tabular}{|c|c|c|c|}
\hline \multirow{2}{*}{ Radionuclide } & \multicolumn{3}{|c|}{ Dose commitment (millurems) } \\
\hline & Total body & Bone & Kidney \\
\hline${ }^{212} \mathrm{~Pb}$ & $61 \mathrm{E}-7$ & $7.6 \mathrm{E}-6$ & $18 \mathrm{E}-5$ \\
\hline${ }^{212} \mathrm{~B} 1$ & $73 \mathrm{E}-9$ & $11 \mathrm{E} \cdot 8$ & $51 \mathrm{E}-7$ \\
\hline${ }^{224} \mathrm{Ra}$ & $41 \mathrm{E}-5$ & $32 \mathrm{E}-4$ & $41 \mathrm{E}-5$ \\
\hline${ }^{228} \mathrm{Th}$ & $48 \mathrm{E}-4$ & $14 \mathrm{E} 2$ & $13 \mathrm{E}-3$ \\
\hline${ }^{232} \mathrm{U}$ & $79 \mathrm{E} 5$ & $11 \mathrm{E}-3$ & $12 \mathrm{E}-4$ \\
\hline${ }^{233} \mathrm{U}$ & $38 \mathrm{E}-6$ & $62 \mathrm{E}-5$ & $14 \mathrm{E}-5$ \\
\hline${ }^{234} \mathrm{U}$ & $65 \mathrm{E}-7$ & $10 \mathrm{E} 5$ & $25 \mathrm{E}-6$ \\
\hline Total doses & $61 \mathrm{E}-4$ & $16 \mathrm{E} 2$ & $15 \mathrm{E}-3$ \\
\hline
\end{tabular}

Table 20. Population dose commitment (man-rems) to total body and various organs due to radionuclide releases to the atmosphere during one year of reprocessing plant operation

\begin{tabular}{cccccc}
\hline Total body & GI tract & Bone & Thyroid & Lungs & Kidneys \\
\hline 392 & 507 & 476 & 601 & 402 & 367 \\
\hline
\end{tabular}


Table 21. Significant contributors to population dose commitment due to radionuclide releases to the atmosphere during reprocessing plant operation

\begin{tabular}{|c|c|c|c|c|c|c|}
\hline \multirow{2}{*}{ Radionuclide } & \multicolumn{6}{|c|}{ Contribution $(\%)$} \\
\hline & Total body & GI tract & Bone & Thyroid & Lungs & Kidneys \\
\hline${ }^{3} \mathrm{H}$ & 74 & 57 & 61 & 48 & 72 & 79 \\
\hline${ }^{14} \mathrm{C}$ & 9.3 & 5.8 & 13 & 2.8 & 4 & 5.7 \\
\hline${ }^{85} \mathrm{Kr}$ & 1 & 1 & 1 & 1 & 2 & 1 \\
\hline${ }^{90} \mathrm{Sr}$ & $<1$ & $<1$ & 4.8 & $<1$ & $<1$ & $<1$ \\
\hline${ }^{106} \mathrm{Ru}$ & 1 & 23 & 1 & 1 & 1 & 1.2 \\
\hline${ }^{129} \mathrm{I}$ & $<1$ & $<1$ & $<1$ & 39 & $<1$ & $<1$ \\
\hline${ }^{137} \mathrm{Cs}$ & 7.3 & 4.0 & 7.4 & 5.1 & 6.5 & 7.2 \\
\hline${ }^{144} \mathrm{Ce}$ & $<1$ & 4.6 & $<1$ & $<1$ & 1 & $<1$ \\
\hline${ }^{220} \mathrm{Rn}+$ daughters & $<1$ & $<1$ & 1 & $<1$ & 2.7 & $<1$ \\
\hline${ }^{228} \mathrm{Th}$ & $<1$ & $<1$ & 1.9 & $<1$ & 2.0 & $<1$ \\
\hline${ }^{232} \mathrm{U}$ & 5.5 & 3.2 & 7.8 & 3.1 & 8.2 & 4.4 \\
\hline $233 \mathrm{U}$ & $<1$ & $<1$ & $<1$ & $<1$ & 1 & $<1$ \\
\hline
\end{tabular}

Table 22. Population dose commitment (man-rems) to total body and various organs due to radionuclide releases to the atmosphere during one year of refabrication plant operation

\begin{tabular}{cccccc}
\hline Total body & GI tract & Bone & Thyroid & Lungs & Kidneys \\
\hline 0.12 & 0.35 & 0.52 & 0.12 & 2.6 & 0.12 \\
\hline
\end{tabular}

\subsubsection{Radiological importance of ${ }^{232} \mathrm{U}$ in recycle of $\left({ }^{232} \mathrm{Th},{ }^{233} \mathrm{U}\right) \mathrm{C}$ fuel}

The decay chain for ${ }^{232} \mathrm{U}\left(t_{1 / 2}=72\right.$ years $)$ contains no "stopping" nuclide such as is found in the

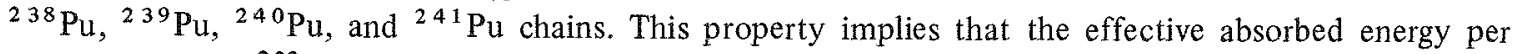
disintegration for ${ }^{232} \mathrm{U}$ is high when compared with most other radionuclide chains. ${ }^{26}$ Estimated levels of the ${ }^{232} \mathrm{U}$ content of fuels range to $>4000 \mathrm{ppm}{ }^{232} \mathrm{U} / \mathrm{U}$. The effect of ${ }^{232} \mathrm{U}$ level on the dose to the maximally exposed individual was calculated for a reprocessing plant and a refabrication plant, with the results shown in Tables 23 and 24. For the reprocessing plant, variation of ${ }^{232} \mathrm{U}$ content from $10 \mathrm{ppm}$ to $5000 \mathrm{ppm}$ raises the total-body dose by only a factor of 1.4 , from 2.8 millirems to 4.0 millirems. The highest dose is delivered to bone, 6.0 millirems for $5000 \mathrm{ppm}{ }^{232} \mathrm{U}$. Similar results for increasing ${ }^{232} \mathrm{U}$ content were observed for population doses.

An increase of ${ }^{232} \mathrm{U}$ content to $5000 \mathrm{ppm}$ had an appreciable effect on the relative dose to the individual exposed to a fuel refabrication facility. However, the resulting absolute dose was still moderate, with values of 0.59 millirem to the total body and 15.1 millirems to the lungs. The population dose also increased, but even at $5000 \mathrm{ppm},{ }^{232} \mathrm{U}$ content does not appear to create an unacceptable insult.

\subsubsection{Radiological importance of tritium in reprocessing of $\left({ }^{232} \mathrm{Th}^{233} \mathrm{U}\right) \mathrm{C}$ fuel}

Tritium can be a major contributor to the dose to individuals and populations in the vicinity of a nuclear fuel reprocessing plant. Its potential contribution to exposure may be even greater than currently 
Table 23. Effects of variation in ${ }^{232} \mathrm{U}$ content on maximum individual dose commitment to total body, bone, and lungs due to radionuclide releases to the atmosphere during one year of reprocessing facility operation

\begin{tabular}{cccc}
\hline${ }^{23} \begin{array}{c}\text { U content } \\
(\mathrm{ppm})\end{array}$ & \multicolumn{3}{c}{ Dose commitment (millirems) } \\
\cline { 2 - 4 } & Total body & Bone & Lungs \\
\hline 10 & 2.8 & 3.5 & 2.6 \\
100 & 2.8 & 3.5 & 2.7 \\
500 & 2.9 & 3.7 & 2.9 \\
1260 & 3.1 & 4.1 & 3.3 \\
2500 & 3.4 & 4.7 & 3.9 \\
5000 & 4.0 & 6.0 & 5.3 \\
\hline
\end{tabular}

Table 24. Effects of variation in ${ }^{232} \mathrm{U}$ content on maximum individual dose commitment to total body, bone, and lungs due to radionuclide releases to the atmosphere during one year of refabrication facility operation

\begin{tabular}{cccc}
\hline${ }^{232} \begin{array}{c}\text { U content } \\
\text { (ppm) }\end{array}$ & \multicolumn{3}{c}{ Dose commitment (millirems) } \\
\cline { 2 - 4 } & Total body & Bone & Lungs \\
\hline 10 & $<0.01$ & $<0.01$ & 0.03 \\
100 & 0.01 & 0.05 & 0.30 \\
500 & 0.06 & 0.25 & 1.5 \\
1260 & 0.15 & 0.63 & 3.8 \\
2500 & 0.29 & 1.3 & 7.5 \\
5000 & 0.59 & 2.5 & 15.1
\end{tabular}

assumed, since recent data ${ }^{27,28}$ predict the yield of ${ }^{3} \mathrm{H}$ from fast fission in various nuclear fuels to be larger than previously calculated. The effects on individual and population doses of increasing the confinement factor from a value of 1 (used in this work) to 100 are shown in Table 25 . The contribution of ${ }^{3} \mathrm{H}$ decreases to a few percent when a confinement factor of 100 is imposed. This does not imply that increased confinement of ${ }^{3} \mathrm{H}$ is needed. Investigators should be aware, however, of the importance of ${ }^{3} \mathrm{H}$ in the source term of a reprocessing facility.

Table 25. Effects of variation in ${ }^{3} \mathrm{H}$ confinement factor on total-body dose commitment due to reprocessing operations

\begin{tabular}{cccccc}
\hline${ }^{3} \begin{array}{c}\text { H confinement } \\
\text { factor }\end{array}$ & \multicolumn{2}{c}{ Maximum individual } & & \multicolumn{2}{c}{ Population } \\
\cline { 2 - 3 } \cline { 5 - 6 } & $\begin{array}{c}\text { Total body dose } \\
\text { (millirems) }\end{array}$ & $\begin{array}{c}\text { Contribution } \\
(\%)\end{array}$ & & $\begin{array}{c}\text { Total body dose } \\
\text { (man-rems) }\end{array}$ & $\begin{array}{c}\text { Contribution } \\
(\%)\end{array}$ \\
\hline 1 & 3.1 & 64 & & 39 & 74 \\
10 & 1.3 & 15 & & 13 & 3 \\
100 & 1.1 & 2 & 11 & 3 \\
\hline
\end{tabular}




\section{CONCLUSIONS}

\subsection{Mining and Milling}

This radiological assessment of thorium mining and milling suggests that the resulting doses should be similar to those from uranium operations. An absolute comparison cannot be made, however, due to differences in some assumptions utilized, including the use of site-specific meteorology and populations at thorium resource sites in the western United States. A distinct difference resulting from the short half-life of ${ }^{220} \mathrm{Rn}\left(t_{1 / 2}=55.6 \mathrm{sec}\right)$ in the thorium decay chain compared to that for ${ }^{222} \mathrm{Rn}\left(t_{1 / 2}=3.82\right.$ days $)$ in uranium decay was found in analyzing emission levels following mill shutdown; release of gaseous and particulate radioactivity from a thorium tailings impoundment can be virtually eliminated with a shallow covering of earth. Also, the residual radioactivity in the thorium tailings decreases rapidly because of the relatively short half-life $\left(t_{1 / 2}=5.75\right.$ years $)$ of ${ }^{228} \mathrm{Ra}$. It was determined that additional information is needed regarding several characteristics of thorium ores and site meteorology to improve the quality of future environmental assessments of thorium mining and milling.

\subsection{Reprocessing and Refabrication}

Airborne doses to the maximally exposed individual and the population were found to be generally less for operation of a refabrication plant than for a reprocessing facility. Tritium is the principal contributor to reprocessing plant doses to both the maximally exposed individual and the population. Carbon-14, ${ }^{137} \mathrm{Cs}$, and ${ }^{232} \mathrm{U}$ account for most of the remaining dose. Dose commitments calculated for the refabrication plant are due almost entirely to ${ }^{220} \mathrm{Rn}$ and its daughters. Only $1 \%$ of the dose is caused directly by ${ }^{232} \mathrm{U}$; however, the ${ }^{220} \mathrm{Rn}$ and daughter content of $(\mathrm{Th}, \mathrm{U}) \mathrm{C}$ fuel in the refabrication plant is roughly proportional to ${ }^{232} \mathrm{U}$ concentration.

Since ${ }^{3} \mathrm{H}$ release and the ${ }^{232} \mathrm{U}$ content of $(\mathrm{Th}, \mathrm{U}) \mathrm{C}$ fuels are important in determining exposure, the effects on dose of a range of ${ }^{3} \mathrm{H}$ confinement factors (CFs) and of ${ }^{232} \mathrm{U}$ concentrations were calculated. A tenfold increase in reprocessing plant CF for ${ }^{3} \mathrm{H}$ reduces the individual and population doses by about $60 \%$. An additional tenfold increase in CF causes an additional 15\% reduction in dose. The strong dependence of the refabrication plant dose on ${ }^{232} \mathrm{U}$ content of the fuel was demonstrated by calculating dose to the individual while varying the ${ }^{232} \mathrm{U}$ content from $10 \mathrm{ppm}$ to $5000 \mathrm{ppm}$. A near-linear dependence was obtained.

A comparison of the radiological impact of recycling $(\mathrm{Th}, \mathrm{U}) \mathrm{C}$ and $(\mathrm{U}, \mathrm{Pu}) \mathrm{C}$ showed little difference. However, the larger content of ${ }^{106} \mathrm{Ru}$ in $(\mathrm{U}, \mathrm{Pu}) \mathrm{C}$ fuel caused an increased GI tract dose from the reprocessing plant. Uranium-232 and ${ }^{228} \mathrm{Th}$, radionuclides specific to the thorium cycle, contribute $10 \%$ of the (Th, U)C fuel dose. The dose from ${ }^{14} \mathrm{C}$ varied somewhat due to variations in content assumed for nitrogen as an impurity in (Th,U)C and $(\mathrm{U}, \mathrm{Pu}) \mathrm{C}$ fuels. The presence of ${ }^{232} \mathrm{U}$ in the (Th,U) fuel (with attendant ${ }^{22} \mathrm{Rn}$ and daughters) causes an appreciable increase in the refabrication plant dose over that previously calculated for (U,Pu)-type fuels.

Release from the $(\mathrm{Th}, \mathrm{U})$ fuel refabrication plant of liquids contaminated to a level typical of that reported for industrial experience in fabricating (U,Pu) fuels contributes little to individual doses.

\section{ACKNOWLEDGMENT}

The authors wish to extend their thanks and acknowledge the contributions that several individuals made in the preparation of this report:

Bettis Atomic Power Laboratory - K. H. Vogel and S. K. Beal provided supplemental information on the assessment of thorium mining and milling as presented in the Light-Water Breeder Reactor Program environmental statement. 
DOE, Grand Junction Office - Eugene W. Grutt, Jr., and Donald L. Hetland provided copies of several reports containing information about thorium deposits in the Lemhi Pass region.

ORNL, Health and Safety Research Division - R. E. Moore performed AIRDOS-II radiological dose calculations, and Don E. Dunning and George G. Killough provided current dose conversion factors for the radionuclides of concern in this report.

ORNL, Chemical Technology Division - Mildred B. Sears provided many helpful suggestions and discussions throughout the course of this study. Hershel W. Godbee contributed to the determination of the applicability of various diffusion models for estimation of ${ }^{220} \mathrm{Rn}$ releases and assisted in the development of the equations for estimating the change in area of the tailings pond during the operation and closing down of the mill. A. G. Croff arranged for the ORIGEN calculations to provide the spent fuel composition.

DOE, Office of Nuclear Energy Programs - The support and encouragement of George L. Sherwood during the performance of this work were also appreciated.

\section{REFERENCES}

1. V. J. Tennery, E. S. Bomar, W. D. Bond, H. R. Meyer, L. E. Morse, J. E. Till, and M. G. Yalcintas, Environmental Assessment of Alternate FBR Fuels: Radiological Assessment of Airborne Releases from Thorium Mining and Milling, ORNL/TM-6474 (October 1978).

2. V. J. Tennery, E. S. Bomar, W. D. Bond, H. R. Meyer, L. E. Morse, and J. E. Till, Environmental Assessment of Alternate FBR Fuels: Radiological Assessment of Reprocessing and Refabrication of Thorium/Uranium Carbide Fuel, ORNL/TM-6493 (August 1978).

3. Energy Research and Development Administration, Final Environmental Statement, Light-Water Breeder Reactor Program, ERDA-1541, Vols. 1-5 (1976).

4. U.S. Atomic Energy Commission, Environmental Survey of the High-Temperature Gas-Cooled Reactor Fuel Cycle-Thorium Mining, Milling, and Refining, 1974 (unpublished).

5. D. W. Buckley, G. L. Simmons, and R. A. Ziskin, "Environmental Impact and Analy sis of Thorium Nuclear Fuel Cycles," Science Applications, LaJolla, Calif. SAI-777-666R-LJ (June 30, 1977).

6. R. E. Moore, The AIRDOS-II Computer Code for Estimating Radiation Dose to Man from Airborne Radionuclides in Areas Surrounding Nuclear Facilities, ORNL-5245 (April 1977).

7. P. E. Morrow, D. V. Bates, B. R. Fish, T. F. Hatch, and T. T. Mercer, "Deposition and Retention Models for Internal Dosimetry of the Human Respiratory Tract," Health Phys. 12, 173 (1966).

8. I. S. Eve, "A Review of the Physiology of the Gastrointestinal Tract in Relation to Radiation Doses From Radioactive Materials," Health Phys. 12, 131 (1966).

9. D. E. Dunning, G. G. Killough, S. R. Bernard, and J. C. Pleasant, Estimates of Internal Dose Equivalent to 22 Organs of Reference Man for Various Radionuclides (Inhalation and Ingestion), Volume II, DOE Report ORNL/NUREG/TM-190/V2 (in preparation).

10. S. R. Borrowman and J. B. Rosenbaum, Recovery of Thorium from Ores in Colorado, Idaho, and Montana, Bureau of Mines Report of Investigation RI 5916 (1962).

11. J. R. Ross and D. R. George, Metallurgical Amenability Tests on Idaho-Montana Thorium Ores, Bureau of Mines Research Report 62.1 (November 1966).

12. G. F. Smith, Purex Plant Chemical Flowsheet for the 1970 Thorium Campaign, ARH-1748 (July 10, 1970).

13. Energy Research and Development Administration, Final Environmental Statement, Light-Water Breeder Reactor Program, ERDA-1541, Vol. 4, Appendix IX-G, June 1976.

14. M. V. J. Culot and K. J. Schaiger, "Radon Progeny Control in Buildings," Colorado State University, Fort Collins, COO-2273-1 (May 1973). 
15. PEDCO-Environmental Specialists, Inc., "Investigation of Fugitive Dust - Sources, Emissions, and Control," PB 226 693, Cincinnati, Ohio, May 1973.

16. M. B. Sears, R. E. Blanco, R. G. Dahlman, G. S. Hill, A. D. Ryon, and J. P. Witherspoon, Correlation of Radioactive Waste Treatment Costs and the Environmental Impact of Waste Effluents in the Nuclear Fuel Cycle for Use in Establishing "As-Low-As Practicable" Guides - Milling of Uranium Ores, ORNL/TM-4903, Vol. 1 (May 1975).

17. P.M. C. Barretto, R. B. Clark, and J. A. S. Adams, Physical Characteristics of Radon-222 Emanation from Rocks, Soils, and Minerals: Its Relation to Temperature and Alpha Dose, the Natural Radiation Environment II, Proceedings of the Second International Symposium on the Natural Radiation Environment, August 7-11, 1972, Houston, Tex., CONF-720805-Ps, ed. J. A. S. Adams, W. M. Lowdeo, and T. F. Gesell.

18. M. T. Mills, R. C. Dahlmann, and J. S. Olson, Ground Level Air Concentrations of Dust Particles from a Tailings Area During a Typical Windstorm, ORNL/TM-4375 (September 1974).

19. P. R. Coleman and A. A. Brooks, A Program to Tally Population by Annuli Sectors, ORNL/TM-3923 (October 1972).

20. V. J. Tennery, E. S. Bomar, W. D. Bond, S. V. Kaye, L. E. Morse, and J. E. Till, Potential Generation and Radiological Impacts of Gaseous ${ }^{14} \mathrm{C}$ Released During Reprocessing of Advanced LMFBR Fuels, ORNL/TM-5538 (June 1976).

21. L. E. Morse, A Conceptual Study for the Reprocessing of Spent Carbide and Nitride Fast Reactor Fuels in Relation to Gasborne Radiological Releases, ORNL-6100 (December 1977).

22. Nuclear Regulatory Commission, Final Generic Environmental Statement on Use of Recycle Plutonium in Mixed-Oxide in Light-Water-Cooled Reactors, NUREG-0002, Chap. 4, Sect. D, p. IV D-29 (August 1976).

23. V. J. Tennery, L. E. Morse, E. S. Bomar, R. D. Seagren, W. D. Bond, L. B. Shappert, G. S. Hill, and J. E. Till, Environmental Assessment of LMFBR Advanced Fuels: A Radiological Analysis of Fuel Reprocessing, Refabrication, and Transportation, ORNL-5230 (1976).

24. U.S. Atomic Energy Commission, Proposed Final Environmental Statement, Liquid-Metal Fast Breeder Reactor Program, WASH-1535, Vol. II, Sec. 4.4 (December 1974).

25. International Commission on Radiological Protection, Publication 9, Pergamon Press, London, 1966.

26. J. E. Till, "Assessment of the Radiological Impact of ${ }^{232} \mathrm{U}$ and Daughters in Recycle ${ }^{23}$ U HTGR Fuel," ORNL/TM-5049 (February 1976).

27. G. Buzzelli, S. Langer, C. Jones, and B. Gainey, "Tritium: Fast Fission Yields of ${ }^{238} \mathrm{U}$ and ${ }^{232}$ Th," Trans. Am. Nucl. Soc. 24, 458 (1976).

28. G. Buzzelli and S. Langer, "Thorium Conversion and Tritium Fission Yields in an EBR-II Irradiation," Trans. Am. Nucl. Soc. 27, 283 (1977). 